\title{
Beyond the Problem of Bone Surface Preservation in Taphonomic Studies of Early and Middle Pleistocene Open-Air Sites
}

\author{
Antonio Pineda ${ }^{1,2}$ (D) Palmira Saladié ${ }^{2,3,4}$
}

Accepted: 4 January 2022 / Published online: 22 January 2022

(c) The Author(s) 2022

\begin{abstract}
A commonly identified problem in open-air sites is the poor preservation of bone surfaces because of the multiple agents and processes that act on them. In these assemblages, surface modifications of anthropic origin can be scarce or null, and its activity is mainly inferred through the stone tools and evidence of anthropogenic breakage. Carnivore activity is also frequent. La Mina and El Forn (Barranc de la Boella), Isernia La Pineta, and Torralba are open-air assemblages from the Early and Middle Pleistocene that have contributed to our knowledge of the activities that Lower Paleolithic hominins developed in open spaces. These sites show poorly preserved bone surfaces, evidence of carnivore activity, and few indications of human use on the faunal remains, although stone tools recovered are unequivocal sign of a hominin presence at those sites. Here, we present a synthesis of the taphonomic conducted at these sites with the aim of describing how this kind of work can be conducted at Paleolithic open-air sites using several different proxies, considering the limitations commonly identified in assemblages with poorly preserved bone surfaces. The absence or scarcity of cut marks could be related to the poor preservation of the faunal remains. However, it is impossible to affirm that any such marks were originally present, as hominins may have performed activities not linked to animal carcasses. Anatomical profiles have been presented as a useful tool for reconstructing the paleoecological environments and for allowing inferences to be made about the levels of competition among large predators. The assemblages reflect similarities in the deposition type of the remains and the use of these open spaces by hominins at different times during the Lower Paleolithic.
\end{abstract}

Keywords Barranc de la Boella · Isernia la Pineta, Torralba · Bone surface modifications · Lower Paleolithic subsistence

Antonio Pineda

apineda.alcala@gmail.com

Extended author information available on the last page of the article 


\section{Introduction}

Pleistocene fossil accumulations may occur in very diverse sedimentary environments, reflecting the different ecological contexts in which archaeological and paleontological sites were set (Butzer, 1982; Shipman, 1981). The sedimentary context also exerts an enormous influence on the conservation conditions of the biological remains deposited (Shipman, 1981). Butzer (1982) synthesized the sedimentary environments in which archaeological assemblages are found, which can be grouped into two types: those formed in covered sedimentary environments, mainly caves and shelters; and those formed in the open-air, which include a wide range of environments, such as water sources or springs, coastlines, lake banks, and marshes or deltaic or river plains.

Covered sedimentary environments usually exhibit greater and better preservation of osteological remains. In these contexts, the bones are deposited in generally more stable temperature and humidity conditions, as, according to Capaldo (1998), they are not completely exposed to meteorological phenomena during the sub-aerial and post-burial phases of their taphonomic history (Brain, 1981). It is in these environments, therefore, where there is a greater possibility of finding well-preserved archaeological remains of biotic origin, especially bones and teeth (Butzer, 1982). This, in turn, makes it possible to perform paleoecological and paleoeconomic reconstructions with, on many occasions, precise interpretations of the different periods of human evolution and, very specifically, paleoeconomic behavior. This interpretations included the identification of, e.g., home bases in early chronologies (Saladié et al., 2011), as well as caves employed as site of communal hunting of large ungulates (Rodríguez-Hidalgo et al., 2017), which is indicative of a high level of territorial control and a high capacity for acquiring and transporting resources to protected habitat sites.

Open-air sites, on the other hand, can also provide a great deal of information on hominin behavior from early chronologies. Domínguez-Rodrigo and Barba (2007a) have proposed the use of open spaces where there could be tree cover for the establishment of home bases in the absence of cavities, while other research suggested the repeated transit of hominins in these spaces for the acquisition of resources of various kinds, in coexistence and cohabitation with other predators (Domínguez-Rodrigo et al., 2007; Egeland, 2008, 2014). Recent taphonomic studies carried out at the late Early Pleistocene open-air site of Barranc de la Boella (Spain) have suggested a greater presence and intensity of hominin activity at times of high competition with other predators (Pineda et al., 2017a). In this site, the almost total absence of pieces of evidence of anthropogenic modification of the carcasses on bone surfaces have let to propose a possible scenario of the formation of the site in which the hominin groups carried out a restricted role in the accumulation and modification of the carcasses. Subsequent revisions of the known assemblages of Isernia La Pineta and Torralba have led researchers to consider, or at least not to rule out, this scenario in the formation of these assemblages, given the low or even zero percentages of anthropogenic intervention on the faunal remains (Pineda \& Saladié, 2019; Pineda et al., 2020). The study of 
these three assemblages has revealed a common problem, which is not unusual in open-air assemblages: the poor preservation of the bone surfaces as a consequence of the multiple processes that end up altering the remains exposed to the elements. From a zooarchaeological and taphonomic point of vsssiew, a correct identification of these processes and its effect on the faunal assemblages is indispensable to avoid misinterpretation of the origin of the bone accumulations and the make correct inferences about the hominin behavior. Processes such as weathering, trampling, hydric abrasion, or lixiviation contribute to the alteration of the bone remains and, where existed, altering or obliterating the bone surface modifications preserved (e.g., Behrensmeyer, 1978; 1986; Shipman \& Rose, 1983b; Cook, 1986; Petraglia \& Potts, 1994; Pineda et al., 2014).

Weathering is one of the most commonly identified processes in open-air sites and is produced by the action of physical and chemical agents operating on biological remains exposed in situ (Behrensmeyer, 1978), which are exposed to more intense and rapid atmospheric changes (Behrensmeyer, 1978; Lam, 1992; Lyman, 1994) and more pronounced temperature and humidity fluctuations (Pokines et al., 2016, 2018). Factors such as temperature and humidity changes, the incidence of sunlight, and freeze-thaw cycles modify any remains deposited on the ground surface (Behrensmeyer, 1978; Junod \& Pokines, 2014; Pokines et al., 2016, 2018; Tuross et al., 1989). Weathering usually may result in the destruction and the disappearance of the remains (Behrensmeyer, 1978), but surviving ones can be deposited and incorporated into the archaeological or paleontological record.

Trampling, although it is obviously not exclusive to open environments, is an important modification in these deposits, which is caused by friction between sedimentary particles and bones. Trampled bones may present striations on their surfaces that can blend in with pre-existing striae, such as cut marks, and even contribute to obliterating any previous marks (Behrensmeyer et al., 1986; Olsen \& Shipman, 1988). Several studies have tried to establish valid criteria for differentiating trampling marks from cut marks (Andrews \& Cook, 1985; Behrensmeyer et al., 1986; Olsen \& Shipman, 1988; Domínguez-Rodrigo et al., 2009a; Courtenay et al., 2019, 2020a, b); however, the high morphological variability of trampling marks (Behrensmeyer et al., 1986; Domínguez-Rodrigo et al., 2009a), the existence of posterior processes that may have further altered the bone surfaces and modifications (Pineda et al., 2014, 2019), and the fact that criteria usually employed to correctly identify trampling marks and differentiate it from cut marks are less objective than originally considered (Domínguez-Rodrigo et al., 2017; Domínguez-Rodrigo, Saladié, et al., 2019) mean that these criteria are still being revised today.

The preservation of remains deposited on river or flood plains, or lake or delta shores, is also affected by the action of flowing water, where internal erosive processes threaten the preservation of the remains (Butzer, 1982). Water flow can cause spatial taphonomic associations of objects, since they tend to segregate from their original positions and form new associations related to their density, weight, and shape, giving rise to lagged or dragged assemblages (Behrensmeyer, 1975; Petraglia \& Potts, 1994; Aslan \& Behrensmeyer, 1986; Pante \& Blumenschine, 2010; Giusti \& Arzarello, 2016; Domínguez-Rodrigo et al., 2018). The influence of flowing water can be identified in assemblages through the rounding and polishing of 
bone edges and surfaces, sometimes completely altering the original morphology of the bones (Shipman \& Rose, 1983a, b; Behrensmeyer et al., 1989; Fernández-Jalvo \& Andrews, 2003; Gaudzinski-Windheuser et al., 2010; Rabinovich et al., 2012), and even modifying and obliterating pre-existing modifications (Behrensmeyer et al., 1989; Gaudzinski-Windheuser et al., 2010; Pineda et al., 2019; Rabinovich et al., 2012; Shipman \& Rose, 1983b).

The presence of water, or simply damp environments, can also lead to processes such as the leaching of soluble elements from sediments or the precipitation of manganese (IV) oxide. When soluble elements are leached from the sediment, subsequent chemical action on the bone surfaces leads to the rapid alteration of any modification (Pineda et al., 2014). In humid and aerobic environments with a neutral or close to neutral $\mathrm{pH}$, the action of bacteria can also cause the precipitation of manganese (IV) oxide; this is evidenced as dark pigmentation of the bone surfaces (Cáceres, 2002; Fernández-Jalvo, 1992; Potter \& Rossman, 1979).

Other biochemical agents, like fungi or bacteria, can also affect osteological assemblages. In the open air, the most common indication of taphonomic processes is root-etching. Produced by the action of fungi (Mychorrizae) and bacteria (Rhizobium), it is evidence of the absorption and transfer of phosphorus from the bones to the roots (Fernández-Jalvo, 1992) and indicative of an environment conducive to plant growth (Lyman, 1994). This process generally produces vermiculation, dendritic grooves characteristic of root growth, which contribute to the dissolution of bone surfaces. These are usually easy to distinguish from anthropic cut marks (Andrews, 1990; Lyman, 1994), although they can be confused with the tooth marks produced by carnivores (Domínguez-Rodrigo \& Barba, 2006, 2007a). Vermiculation can affect remains either prior to or during the burial phase (Cook, 1986; Lyman, 1994), although it usually affects buried remains (Fernández-Jalvo \& MarínMonfort, 2008) and requires relatively long exposure times (Cook, 1986; Fernández-Jalvo \& Marín-Monfort, 2008).

The action of all these processes and agents on open-air Pleistocene osteological assemblages has contributed to altering bone surfaces and modifications on them, such as cut marks and tooth marks, obliterating these and even generating new marks (Shipman \& Rose, 1983b; Behrensmeyer et al., 1986, 1989; Olsen \& Shipman, 1988; Domínguez-Rodrigo et al., 2019a; Gaudzinski-Windheuser et al., 2010; Rabinovich et al., 2012; Pineda et al., 2014, 2019). The primary consequence is that they hinder zooarchaeological research focused on the nutritional phase of the carcasses (Egeland, 2008), the purpose of which, among other things, is to determine the activities carried out by hominin groups and their relationship with the fauna of the environments they inhabited. The action of these processes also makes it harder to pinpoint the role hominins played in the formation of Pleistocene accumulations in open-air sites (e.g., Behrensmeyer, 1978; Shipman, 1981; Shipman \& Rose, 1983b; Behrensmeyer et al., 1986; Olsen \& Shipman, 1988; Domínguez-Rodrigo \& Barba, 2006, 2007a; Egeland, 2008; Egeland \& Domínguez-Rodrigo, 2008; MarínArroyo et al., 2008; Domínguez-Rodrigo et al., 2019a; 2009b; Pineda et al., 2014; Yravedra et al., 2016; Courtenay et al., 2020a).

The recognition of different associations between stone artifacts and faunal remains in the archaeological record has been employed to differentiate various 
types of assemblages in which hominin activities can be more or less intense (Isaac \& Crader, 1981; Leakey, 1971). These are interpreted, for example, as base camps factory or butchering sites. The various types of occupations can be characterized by differences in the presence/absence of certain artifacts and/or bone remains, and by the spatial relationships between the different types of objects (Carr, 1984, 1987; Domínguez-Rodrigo \& Cobo-Sánchez, 2017; Isaac \& Crader, 1981; Kroll \& Price, 1991; Leakey, 1971; Whitelaw, 1991).

Home bases are defined as residential camps occupied for some length of time or usually reoccupied in which hominin groups carried out their daily live activities and related with subsistence (Isaac, 1971, 1978). Home bases have been identified in early chronologies, such as the FLKK and BK in Olduvai Gorge (DomínguezRodrigo et al., 2002; 2009b; Domínguez-Rodrigo \& Barba, 2007a), as well as Level TD6.2 at the Gran Dolina site (Saladié et al., 2011, 2014) in the Sierra de Atapuerca. However, during the Middle Pleistocene, the archaeological record reveals an expansion and diversification of this type of assemblage, including the German site of Bilzingsleben (Mania \& Mania, 2005); Orgnac 3 (Moncel et al., 2005, 2012), Payre (Moncel et al., 2007) and Aragó Cave (Moigne, 1983; Moigne \& Barsky, 1999) in France; and Level Td10.1 at Gran Dolina (Rodríguez-Hidalgo et al., 2015) and Bolomor Cave (Blasco, 2008; Blasco \& Fernández-Peris, 2009) in Spain. Out of Europe, the Israeli site of Qesem Cave (Blasco et al., 2016; Stiner et al., 2009) or the Middle Stone Age African sites of Klasies River Mouth in South Africa (Klein, 1978, 1982) has been described as home bases.

Other types of accumulations are not a manifestation of residential areas, but reflect activities directly related to the procurement of resources, generally of animal origin, referred to as kill/butchering sites. The processing of large ungulates acquired by hunting has been documented at sites such as Schöningen (Voormolen, 2008), Cuesta de la Bajada (Domínguez-Rodrigo et al., 2015), and Gran Dolina level TD10.2 (Rodríguez-Hidalgo et al., 2017). Other sites show evidence of megaherbivorous carcass exploitation, including proboscidean carcasses like in Olorgesailie (Kübler et al., 2015), Fuente Nueva 3 (Espigares et al., 2013), Notarchirico (Moncel et al., 2020), and Áridos 1 and Áridos 2 (Ollé, 2005; Yravedra et al., 2010), although the mode of acquisition is unknown; hippopotamus, such as in the hippopotamus/artifact site (HAS) locality of Koobi Fora in Kenya (Isaac, 1971; Isaac \& Crader, 1981); or giraffe, such has been proposed in ST4 (Peninj) (DomínguezRodrigo et al., 2002). A third type of fossil assemblage, such as the Galería complex, has been interpreted as natural traps, where hominin groups would have had access to the carcasses of fallen animals (Cáceres, 2002; Díez Fernández-Lomana, 1993; Huguet et al., 1999). In this type of environment, we are also able to identify accumulations resulting from the superposition of independent events produced in more or less extensive periods of time. Lake shores, deltaic limits, and flood plains are excellent places for settlements, but also for the exploitation of various resources (vegetables, meat, water or raw materials), therefore being places of transit for Pleistocene foragers and carnivores (Binford, 1983). Added to this archaeological evidence is the possible transport of remains in catastrophic flows, and accumulations produced by the natural deaths of animals. For this reason, these contexts often involve several actors and processes that would have played different roles and 
participated in the formation of the deposits, with no single agent standing out as the main accumulator.

The recent taphonomic reviews of the late Early Pleistocene open-air site of Barranc de la Boella (Tarragona, Spain), and the Middle Pleistocene sites of Isernia La Pineta (Molise, Italy) and Torralba (Soria, Spain) have revealed the existence of common problems that have conditioned taphonomic studies (Fig. 1). These are open-air sites in areas of presumed availability of resources of various kinds in which human presence is clearly attested through the stone tools recovered, but the poor preservation of the bone surfaces and the modifications on them prevent the identification of anthropogenic intervention of the carcasses and limit subsistence interpretations linked to the exploitation of this type of material. The aim of the present manuscript is to expose the problem commonly associated with this type of assemblages from a holistic perspective and to discuss how these faunal assemblages could be studied in view of the poor preservation of bone surfaces and the modifications on them.

\section{Barranc de la Boella (Tarragona, Spain)}

The Barranc de la Boella gully is located in the municipality of la Canonja, $3 \mathrm{~km}$ from the city of Tarragona. The excavation work began in 2007, since which time there have been interventions in three different pits: Pit 1 (P1), La Mina (LM), and El Forn (EF), located on both sides of the gully, with a distance of no more than $200 \mathrm{~m}$ between all of them (Fig. 2).

Barranc de la Boella presents a lithostratigraphic sequence of $9 \mathrm{~m}$ in which six lithostratigraphic units have been identified, named I-VI from bottom to top, and described in detail in Vallverdú et al. (2014b). All three pits share the same lithostratigraphic sequence, although archaeological levels are not correlated between them. The majority of the material recovered in the gully is concentrated in various archaeo- and paleontological levels identified in Unit II. This unit comprises a 2-m homogeneous sequence of poorly stratified sands and gravel, characteristic of

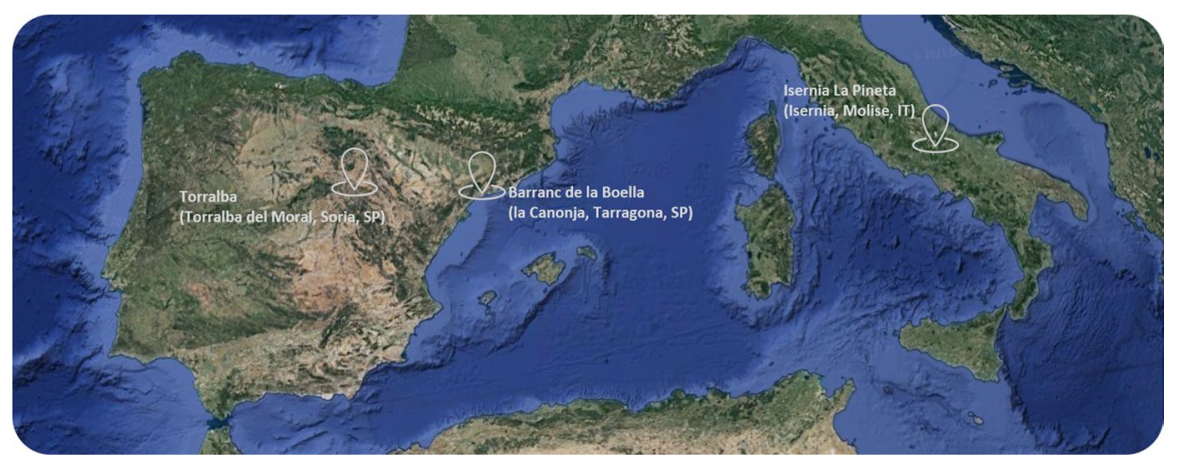

Fig. 1 View of the Western Mediterranean region and location of Barranc de la Boella, Isernia La Pineta and Torralba sites in the Iberian and Italian Peninsula 

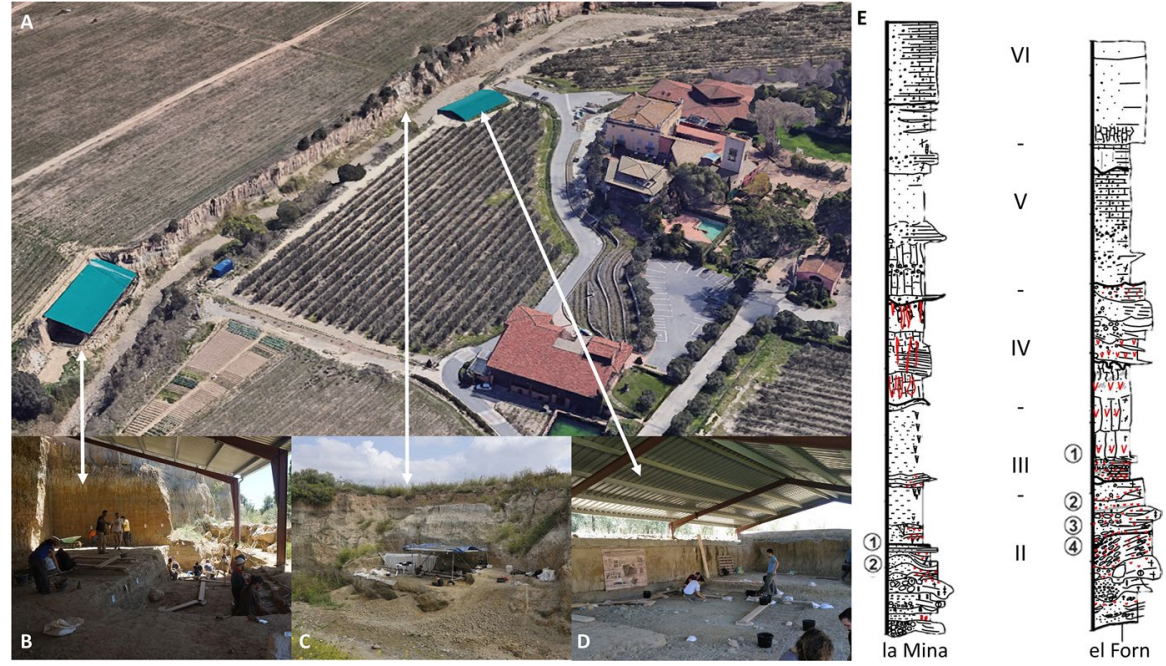

Fig. 2 A Panoramic view of the Barranc de la Boella site. White arrows indicate the place of each site; (B) View of La Mina site and location in the gully; (C) View of El Forn and location in the gully; (D) View of Pit 1 and location in the gully; (E) Lithostratigraphic units and archeopaleontological levels identified at La Mina and El Forn (Modified from Vallverdú et al., (2014a, b))

subaerial and underwater mass flow deposits (Vallverdú et al., 2014a). The unit has been dated using biochronology, paleomagnetism, and cosmogenic nuclides as late Early Pleistocene, ca. 960-781 Ka (Lozano-Fernández et al., 2014; Vallverdú et al., 2014b).

Work in Pit 1 has focused on level II.2, from which multiple remains of Mammuthus meridionalis have been recovered, including a pair of tusks, teeth, skull fragments, ribs, and a scapula, associated with 125 lithic artifacts (Mosquera et al., 2015, 2016; Vallverdú et al., 2014b), in an area of $13 \mathrm{~m}^{2}$. At La Mina, four archaeological levels have been documented in a surface of $40 \mathrm{~m}^{2}$. To date, level II.2, which ranges between 30 and $65 \mathrm{~cm}$, is the most prolific, with over 500 faunal remains and more than a hundred lithic remains recovered. From level II.3, on the other hand, more than 200 hyena coprolites have been recovered, and it has been identified as a latrine. Finally, at El Forn, seven levels have been identified in an excavated area of $68 \mathrm{~m}^{2}$, belonging to the units III (EF1) and II (EF2-EF7). The higher levels (EF1EF4), which ranges between $\sim 20$ and $40 \mathrm{~cm}$ each, concentrate the largest number of remains and where taphonomic studies have been focused. In sum, data presented in this work provide from level II. 2 of Pit 1, level II. 2 of La Mina (LM2) and levels 1 to 4 of El Forn site (EF1-EF4).

\section{Barranc de la Boella Archaeological Sample}

Barranc de la Boella has provided an extensive faunal record of macromammals of diverse taxa, with 1786 remains distributed between Pit 1 , level II.2 $(n=480)$, 
La Mina, Level II.2 ( $n=578)$, and the different levels of El Forn (EF1 to EF4) $(n=718)$ (Tables 1 and 2). The well-represented taxa are medium and large ungulates (e.g., Equus altidens, Dama vallonnetensis, and Megaloceros sp.) and megaherbivores (Mammuthus meridionalis, Hippopotamus antiquus, and Stephanorhinus hundsheimensis). The taxonomic list also includes a wide variety of carnivores (Ursus sp., Panthera sp. (large), Canis mosbachensis, Vulpes sp., Lynx sp., and a large felid), although all but the bear remains are scarce (Madurell-Malapeira et al., 2019). The presence of hyenas has been inferred through traces of their activity, mainly in the form of coprolites and modifications of the osteological complex (Pineda et al., 2017a; Vallverdú et al., 2014b). The micromammals

Table 1 Taxonomic list of macromammals recovered from the three areas excavated at Barranc de la Boella. NISP/MNE/MNI. Data from Mosquera et al. (2016) and Pineda et al. (2017b)

\begin{tabular}{|c|c|c|c|c|c|c|}
\hline Taxa & $\begin{array}{l}\text { Pit } 1 \\
\text { II. } 2\end{array}$ & $\begin{array}{l}\text { La Mina } \\
\text { II. } 2\end{array}$ & $\begin{array}{l}\text { El Forn } \\
\text { III.1 }\end{array}$ & $\begin{array}{l}\text { El Forn } \\
\text { II. } 2\end{array}$ & $\begin{array}{l}\text { El Forn } \\
\text { II. } 3\end{array}$ & $\begin{array}{l}\text { El Forn } \\
\text { II. } 4\end{array}$ \\
\hline Macaca sylvanus & - & $1 / 1 / 1$ & - & - & - & - \\
\hline Mammuthus meridionalis & $160 / 9 / 2$ & $1 / 1 / 1$ & - & $1 / 1 / 1$ & $1 / 1 / 1$ & $6 / 5 / 1$ \\
\hline Hippopotamus antiquus & - & $5 / 1 / 1$ & $1 / 1 / 1$ & $5 / 2 / 1$ & $6 / 4 / 2$ & $12 / 10 / 2$ \\
\hline Stephanorhinus hundsheimensis & - & - & $2 / 2 / 1$ & $3 / 2 / 1$ & $3 / 2 / 1$ & $7 / 4 / 1$ \\
\hline Dama vallonnetensis & $4 / 4 / 2$ & $49 / 23 / 3$ & $21 / 10 / 2$ & $13 / 7 / 2$ & $18 / 14 / 2$ & $13 / 9 / 3$ \\
\hline Megaloceros sp. & - & $5 / 3 / 2$ & $3 / 2 / 1$ & $1 / 1 / 1$ & $1 / 1 / 1$ & $3 / 3 / 1$ \\
\hline Cervidae indet - medium/small sized & - & $24 / 4 /-$ & $16 / 2 /-$ & $5 /-/-$ & $6 / 1 /-$ & $13 / 5 / 1$ \\
\hline Equus altidens & $1 / 1 / 1$ & $20 / 15 / 2$ & $31 / 12 / 2$ & $17 / 7 / 2$ & $10 / 8 / 1$ & $15 / 14 / 3$ \\
\hline Bovini sp. & - & $3 / 3 / 1$ & - & $1 / 1 / 1$ & $1 / 1 / 1$ & $2 / 2 / 1$ \\
\hline Sus strozzi & - & - & $1 / 1 / 1$ & - & - & - \\
\hline Castor sp. & - & - & - & - & - & $1 / 1 / 1$ \\
\hline Ursus sp. & - & $11 / 10 / 1$ & - & - & - & - \\
\hline Panthera sp. (medium sized) & - & $1 / 1 / 1$ & - & - & - & - \\
\hline Felidae (large sized) & - & $1 / 1 / 1$ & - & - & - & - \\
\hline Canis mosbachensis & - & $3 / 1 / 1$ & - & - & - & - \\
\hline Vulpes sp. & - & $1 / 1 / 1$ & - & - & - & $1 / 1 / 1$ \\
\hline Lynx sp. & - & $1 / 1 / 1$ & - & - & - & - \\
\hline Chelonia & - & $1 / 1 / 1$ & - & - & - & - \\
\hline Leporidae & - & $14 / 14 / 1$ & - & - & $1 / 1 / 1$ & - \\
\hline Aves & - & $3 / 3 / 1$ & $1 / 1 / 1$ & $1 / 1 / 1$ & $1 / 1 / 1$ & - \\
\hline Total (NISP/MNE/MNI) & $165 / 14 / 5$ & $144 / 89 / 22$ & $76 / 32 / 10$ & $47 / 24 / 11$ & $48 / 34 / 12$ & $75 / 55 / 17$ \\
\hline Very large sized & $306 /-/-$ & $14 /-/-$ & 8/-/- & $4 /-/-$ & $4 /-/-$ & $13 /-/-$ \\
\hline Large sized & - & $53 /-/-$ & $30 /-/-$ & $34 /-/-$ & $11 /-/-$ & $42 /-/-$ \\
\hline Medium sized & 6/3/- & $145 /-/-$ & 29/-/- & 27/-/- & $36 /-/-$ & 43/-/- \\
\hline Small sized & - & $55 /-/-$ & 6/-/- & $7 /-/-$ & 9/-/- & $12 /-/-$ \\
\hline Indeterminate & 72/-/- & $167 /-/-$ & 28/-/- & $52 /-/-$ & $26 /-/-$ & $52 /-/-$ \\
\hline Total (NR) & 549 & 578 & 177 & 171 & 134 & 236 \\
\hline
\end{tabular}


Table 2 Quantification of the different remains recovered in the assemblages studied.

\begin{tabular}{llllll}
\hline Site & Level & Bones & Teeth & Coprolites & Stone tools \\
\hline Pit 1 (BB) & II.2 & 472 & 77 & - & 125 \\
La Mina (BB) & LM2 & 499 & 79 & 38 & 80 \\
El Forn (BB) & EF1 & 146 & 31 & 2 & 7 \\
& EF2 & 145 & 26 & - & $100^{*}$ \\
& EF3 & 114 & 20 & - & \\
Isernia La Pineta & 3 coll & 5128 & 572 & - & 7 \\
Torralba & B1 & 582 & 74 & - & $? * *$ \\
& B2 & 548 & 78 & - & $1529 * * *$ \\
& B4 & 367 & 48 & - & \\
& B5 & 125 & 18 & - & \\
\hline
\end{tabular}

BB data from Mosquera et al., $(2015,2016)$ and Pineda et al. (2017b); Isernia data from Peretto et al. (2015) and Pineda et al. (2020); Torralba data from Sánchez-Cervera et al. (2015) and Pineda and Saladié (2019). *Quantification of EF2-3 stone tools is shown together by Mosquera et al. (2016). **Preliminary data about stone tools presented by Peretto et al. (2015) do not provide a number of stone tools for $3 \mathrm{col}$ level. ***Quantification of Torralba stone tools from Cerralbo and Howell periods are shown together by SánchezCervera et al. (2015)

described from Barranc de la Boella are Mimomys savini, Victoriamys chalinei, Talpa sp., and Crocidura sp. (Lozano-Fernández et al., 2014).

Hominin activity has been documented principally through large technological assemblages recovered from the three pits: 125 remains from Pit 1, level II.2; 100 from EF1 to EF4; and 80 from La Mina II.2 (Mosquera et al., 2015, 2016). The excavation surfaces of Pit 1 and La Mina are currently being expanded and the excavation is ongoing. According to Mosquera et al. (2016), the three pits show a similar record, mainly comprising simple and retouched flakes, generally denticulate and notched, cores, and "percussion materials." The knapping methods were unipolar longitudinal and centripetal, and the raw materials are local, with chert being employed for flake acquisition and quartzite, hard-wearing schist, and porphyry used as percussion materials and for large cutting tools, including a schist pick from Pit 1 and a cleaver-like tool recovered from El Forn (Mosquera et al., 2015, 2016; Vallverdú et al., 2014b) (Table 2).

Many osteological remains exhibit bone surface preservation problems, displaying taphonomic modifications such as weathering, hydric abrasion, or chemical alteration as a consequence of leaching (Table 3) (Fig. 3). Weathering affects $50 \%$ of the sample from levels EF2 and EF3. For LM2, water abrasion has been documented as affecting more than $50 \%$ of the sample. The correlation of the mineral density of bones with the \%MAU applying the Spearman's rho suggests a small, positive, statistically significant relationship between the preserved remains and their structural density for medium and large animals, with the exceptions of large carcasses on EF2 and Ef4, in which there was an absence of significance $(p>0.05)$ (Table 4$)$. 


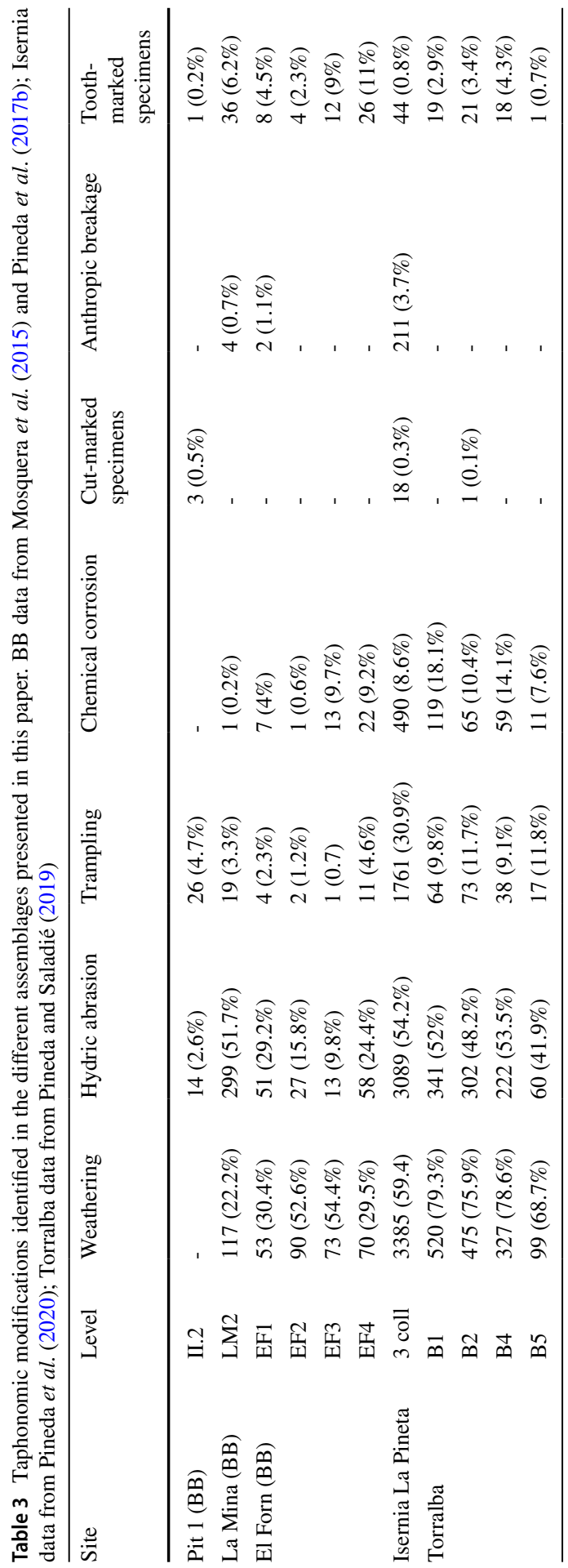




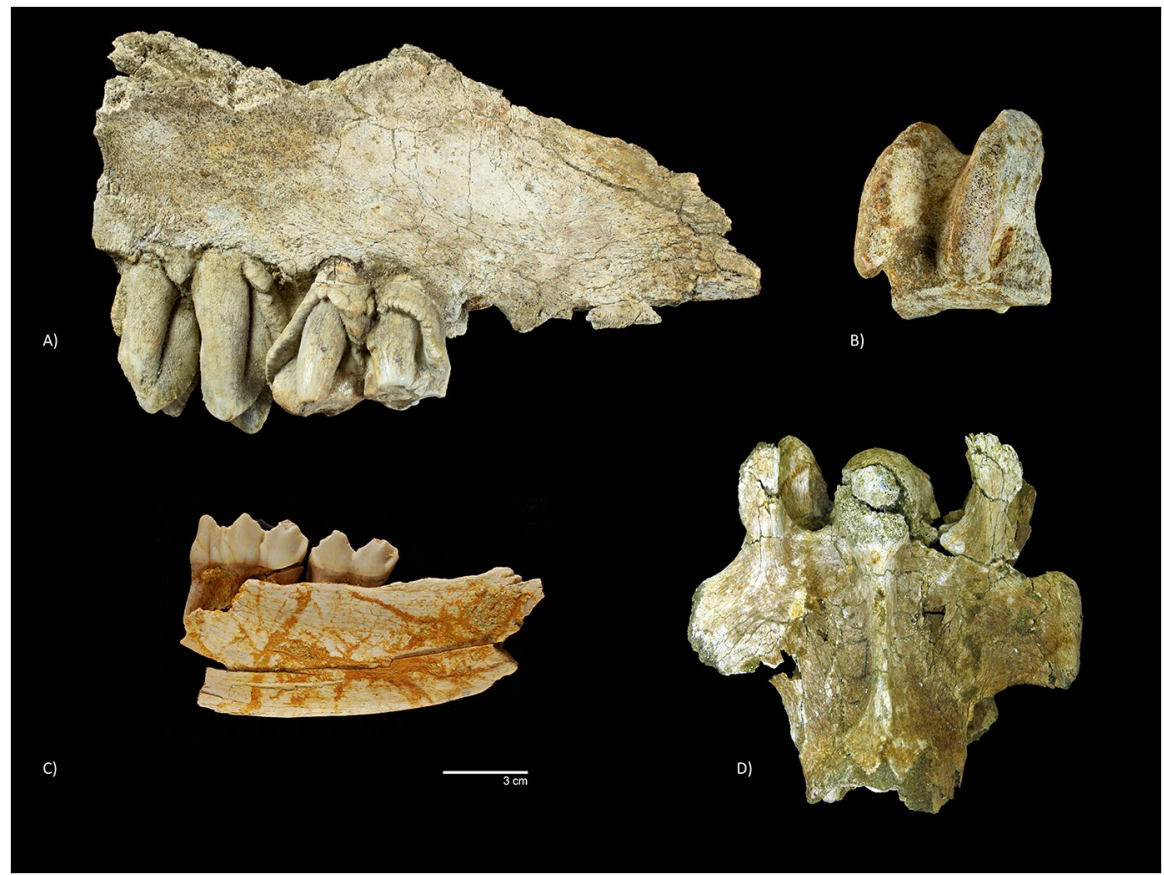

Fig. 3 Remains recovered from Barranc de la Boella with evidence of bone surface alteration: (A) hippopotamus maxilla; (B) horse astragalus; (C) deer jaw; (D) horse vertebra

The poor preservation of the bone surfaces could be responsible for the almost total absence of taphonomic evidence of the anthropic processing of the fauna in the different pits. Anthropic breakage has been identified in four limb bones showing clear percussion marks at La Mina, level II.2 (a humerus from a bovid and a humerus, a femur, and a metatarsal from a deer), and two more have been recovered from el EF1 (two shafts of a medium-sized animal) (Pineda et al., 2017b). This evidence accounts for less than $1 \%$ of the total, and is absent in the other levels.

To address this problem, two experimental studies were performed to describe how chemical and mechanical alteration of bone surfaces can affect cut and trampling marks, hindering or preventing their identification and correct differentiation during taphonomic studies (Pineda et al., 2014, 2019). In Pit 1, level II.2, Mosquera et al. (2015) identified three possible cut marks on two mammoth ribs; although they were poorly preserved, they did display some diagnostic criteria (a v-shaped morphology and symmetrical section), associated with cut marks (Mosquera et al., 2015). Additionally, in La Mina II.2, 21 striae of uncertain origin were identified, mostly on deer remains (jaw, humerus, and femur), on a medium-sized limb bone, a bison atlas, and the rib of a very-large sized animal (Pineda et al., 2014, 2017b). These striae had been affected by processes such as abrasion, so the agent that had originated them was not determined in the taphonomic studies. However, the experimental study and statistical treatment of mechanically altered cut marks and trampling striae conducted by Pineda et al. (2019) does suggest a relationship between 
Table 4 Correlation of the mineral density of the bones with the \%MAU of the different assemblages. Data are presented for medium and large-sized carcasses

\begin{tabular}{llllll}
\hline Site & Assemblage & Weight category & Correlation $\left(r^{2}\right)$ & Spearman's rho & $p$ \\
\hline Barranc de la Boella & LM2 & Medium & 0.14 & 044 & $<0.01$ \\
& & Large & $0.002 \mathrm{~s}$ & 0.21 & $<0.005$ \\
& EF1 & Medium & 0.05 & 0.23 & $<0.05$ \\
& & Large & 0.03 & 0.20 & $<0.05$ \\
& EF2 & Large & 0.01 & 0.15 & $>0.05$ \\
& EF3 & Medium & 0.16 & 0.34 & $<0.01$ \\
& Large & 0.06 & 0.24 & $<0.05$ \\
& EF4 & Medium & 0.03 & 0.32 & $<0.01$ \\
& & Large & 0.08 & 0.19 & $>0.05$ \\
Isernia La Pineta & Medium & 0.04 & 0.24 & $<0.05$ \\
& & Large & 0.02 & 0.26 & $<0.05$ \\
Torralba & B1 & Medium & 0.04 & 0.19 & $>0.05$ \\
& & Large & 0.06 & 0.33 & $<0.01$ \\
& B2 & Medium & 0.07 & 0.36 & $<0.01$ \\
& & Large & 0.10 & 0.4 & $<0.01$ \\
& B4 & Medium & 0.01 & 0.08 & $<0.01$ \\
& \multirow{2}{*}{ B5 } & Large & 0.07 & 0.3 & $<0.01$ \\
& Medium & 0.03 & 0.03 & $>0.05$ \\
& Large & 0.002 & -0.14 & $>0.05$ \\
\hline
\end{tabular}

the altered cut marks and those identified in Pit 1. At La Mina, it was possible to establish the morphological features of marks altered by trampling in the majority of cases, although, from a statistical point of view, some of the marks were more similar to altered cut marks (Pineda et al., 2019).

Carnivore activity has been documented at both La Mina and El Forn, with modifications affecting around $10 \%$ of the sample over the different levels studied. The majority of these modifications are documented as scores and pits on the bone surfaces. A comparison with metric data from current samples identifies the intervention of at least one large carnivore as having modified the assemblages. Other types of modification have also been documented, including the furrowing of limb bone epiphyses, pitting, and bones affected by gastric acids. The intensity of these modifications, which include the complete destruction of mammoth and rhinoceros epiphyses, is indicative of hyenas as modifying agents (Haynes \& Klimowicz, 2015). In line with this, hyena coprolites have also been identified in all the assemblages, in particular the latrine identified in La Mina level II.3.

An anatomical profile study, in agreement with the evidence of hominin and carnivore presence, shows coincidence of the activity of the two agents during the formation of the assemblages. The proxies for measuring competition in the environment suggest that the times of the most intense carnivore activity were also when there was the greatest human presence. LM level II.2 is the clearest example of this trend. This assemblage is characterized by the presence of abundant remains of lithic industry made 
from different raw materials and involving various tool types. In addition, remains have been found that evidence anthropogenic breakage, as well as abundant marks produced by carnivores. According to the analysis of the anatomical profiles, the ravaging and, therefore, the competition among predators (intra- or interspecific) may have reached high levels of intensity.

\section{Interpretation of the Assemblages}

The paleoecological environment inferred during the formation of Unit II at Barranc de la Boella seems to correspond to a deltaic ecosystem, as evidenced by the high incidence of aquatic (Hippopotamus antiquus, Castor sp., and Mimomys savini) and openair (e.g., Mammuthus meridionalis and Equus altidens) species, consistent with the sedimentological descriptions (Rosas et al., 2015; Vallverdú et al., 2014b). The possible existence of riparian forests has also been described, with the presence of plant taxa such as pines (Pinus sp.), junipers (cf. Juniperus), hazel (Corylus), olives (Olea-Phillyrea), and birches (Betula), as well as animals that inhabited these spaces, like macaque and wild boar. In this inferred environment, a wide variety of resources including meat, vegetables, water, and raw materials for stone tool production would converge, and be within the reach of the hominin populations that transited through this space.

Hominin access to meat resources is reflected in Pit 1, level II.2. The detailed study of the assemblage has revealed that Mammuthus meridionalis accounts for $>99 \%$ of the remains. The spatial distribution and refits identified show the use of few cores to obtain flakes. The use-wear analyses of several flakes makes it possible to relate their use to butchery activities (Mosquera et al., 2015) and this has been interpreted as a butchering site, reflecting a single event of mammoth carcass acquisition by human groups (Mosquera et al., 2015).

The archaeological levels of La Mina (LM2) and El Forn (EF1 to EF4) can be interpreted as spatial palimpsests, in which different events of various characteristics and specificities have not been distinguished. The faunal remains are very fragmented in most cases. The presence of hominins in the environment has been identified principally through the presence of the stone tools recovered from the sites (Mosquera et al., 2016), since there is scant evidence of carcass processing. The carnivore activity, documented mainly based on the modifications produced on the osteological assemblage, has been described as related to events independent from those of the hominins. Under these conditions, it has been proposed that the presence of the hominin groups could have been related to foraging activities, without there necessarily having been a direct relationship with the acquisition of animal carcasses (Pineda et al., 2017b).

\section{Isernia La Pineta (Molise, Italy)}

The Isernia La Pineta site is located in the south-central part of the Italian Peninsula, in the town of Isernia (Molise, Italy). It was discovered in the late 1970s, during the construction of a highway. Since its discovery, excavation work at Isernia has been active for more than four decades (Peretto et al., 2015). 
Peretto and colleagues recently described the complete stratigraphy of Isernia (Peretto et al., 2015; Fig. 2). Four major unconformity-bounded stratigraphic units (UBSUs) have been identified (referred to as UBSU 1-4), interspersed with four paleosols (S1-S4) (Coltorti et al., 1982, 2005; Peretto et al., 2015; Thun Hohenstein et al., 2009). UBSU 4, the oldest, has been dated as being from around the Early-Middle Pleistocene boundary, while the subsequent one (UBSU 3) contains deposits dated as Middle Pleistocene (Peretto et al., 2015). This UBSU comprises sands, gravels, and salts that contain a series of levels of coarse-grained pyroclasts (pumice) (Coltorti \& Pierucchini, 2014).

Four archeosurfaces have been identified and excavated in two different sectors of the site: 3c, 3a, and 3s10, in sector I; and 3a in sector II (Peretto et al., 2015). The four archeosurfaces, which are very differentiated in the stratigraphic sequence, are distinguished by their extent and the density and degree of conservation of the fossil remains (Thun Hohenstein et al., 2009). In addition to the aforementioned archeosurfaces, various fossiliferous levels have been identified. Level 3 Colluvio (3 coll), with an excavated surface of $100 \mathrm{~m}^{2}$, is one of the most prolific of the site. A taphonomic review of the faunal materials has recently been conducted, from which the data included in this study are derived. This level is located on the third archeosurface of sector I (Marrocchino \& Vaccaro, 2006; Thun Hohenstein et al., 2009). 40Ar/39Ar dating performed after the discovery of a human remnant (Homo sp. cf. heidelbergensis) provided a chronology of 583-561 ka (Peretto et al., 2015).

\section{The Isernia La Pineta, Level 3 Colluvio Archaeological Record}

Isernia La Pineta has an extensive record of macromammals, both bone and teeth (Table 2), being the remains of Bison schoetensacki, Palaeoloxodon antiquus, and Stephanorhinus hundsheimiensis predominant. Other ungulates represented at the site are Hippopotamus cf. antiquus, Premegaceros solilhacus, Cervus elaphus cf. acoronatus, Dama cf. roberti, Capreolus sp., Sus scrofa, and Hemitragus cf. bonali. Among the carnivores, the most abundant remains are from Ursus deningeri, although other taxa have also been identified, including Panthera pardus and Panthera leo fossilis (Ballatore \& Breda, 2013; Breda et al., 2015; Peretto et al., 2015; Sala, 1996; Thun Hohenstein et al., 2005, 2009). A deciduous upper incisor (possibly di2) identified as belonging to Homo sp. cf. heidelbergensis (Peretto et al., 2015), as well as some bird (Tonon, 1989) and leporid (Thun Hohenstein et al., 2009) remains complete the taxonomic list (Table 5). In this work, a taphonomic analysis of the entire 3 coll assemblage is presented, with the exception of the human tooth.

The surfaces of the bones from level 3 coll show signs of alteration due to the action of processes such as weathering, which affects $59.4 \%$ of the remains, and modifications produced by water abrasion, which affects $54.2 \%$ of the osteological sample. Other modifications identified are trampling striae and notches, which affect $30.9 \%$ of the remains, chemical corrosion $(8.6 \%)$, and root-etching (7.9\%) (Table 3) (Fig. 4). The correlation of the mineral density to the \% MAU 
Table 5 Taxonomic list of macromammal remains recovered from Isernia $\mathrm{La}$ Pineta, level 3 coll. Data from Peretto et al. (2015) and Pineda et al. (2020)

\begin{tabular}{llll}
\hline Taxa & NISP & MNE & MNI \\
\hline Homo sp. cf. Heidelberguensis & 1 & 1 & 1 \\
Palaeoloxodon antiquus & 110 & 8 & 2 \\
Hippopotamus cf. antiquus & 8 & 2 & 1 \\
Stephanorhinus hundsheimensis & 166 & 55 & 2 \\
Bison schoetensacki & 423 & 125 & 8 \\
Bison/rhino & 48 & 11 & - \\
Praemegaceros solihacus & 8 & 6 & 2 \\
Cervus elaphus cf. acoronatus & 4 & 3 & 1 \\
Dama cf. roberti & 1 & 1 & 1 \\
Cervidae & 50 & 6 & - \\
Sus scrofa & 5 & 4 & 2 \\
Hemitragus cf. bonali & 5 & 4 & 1 \\
Capreolus sp. & 1 & 1 & 1 \\
Artiodactyla & 15 & - & - \\
Herbivorous indet & 51 & - & - \\
Ursus deningeri & 114 & 42 & 3 \\
Panthera pardus & 1 & 1 & 1 \\
Canis mosbachensis & 1 & 1 & 1 \\
Carnivora & 8 & 1 & - \\
Aves & 1 & 1 & 1 \\
Cf. Oryctolagus & 5 & 4 & 1 \\
Total (identified) & 1026 & 2277 & 29 \\
Indeterminate & 4675 & - & - \\
Total & 5701 & - & - \\
\hline & & &
\end{tabular}

was positive and significant for medium (rho $=0.24 ; p=<0.05)$ and large sized carcasses (rho $=0.26 ; p=<0.05$ ) (Table 4).

Anthropogenic modifications are scarce in level 3 coll and, indeed, throughout the whole Isernia La Pineta sequence (Anconetani, 1996a, b; Anconetani \& Peretto, 1996; Thun Hohenstein et al., 2005; 2009), possibly due to the poor preservation of the bone surfaces. In level 3 coll, 18 remains $(0.3 \%)$ present cut marks: on a bison's jaw, humerus, and tibia; on a rhino's cranial fragment and femur; on a bear's undetermined metapodial; and on an elephant shaft fragment. Also were found on non-identified specimens: six shaft fragments, one cranial fragment, one large sized vertebra, and on three unidentified remains. All cut mark located on limb bones were identified on the mid-shaft (Pineda et al., 2020).

Anthropogenic breakage, identified by preservation of percussion marks and notches, is the main evidence of hominin activity, having been documented in 211 remains $(3.7 \%)$ from level 3 coll. This breakage is mainly seen in the long bones $(n=153)$ of bison, especially femora and humeri, although it has also been documented in flat bones, mainly jaws from bison $(n=8)$ and bears $(n=1)$. 


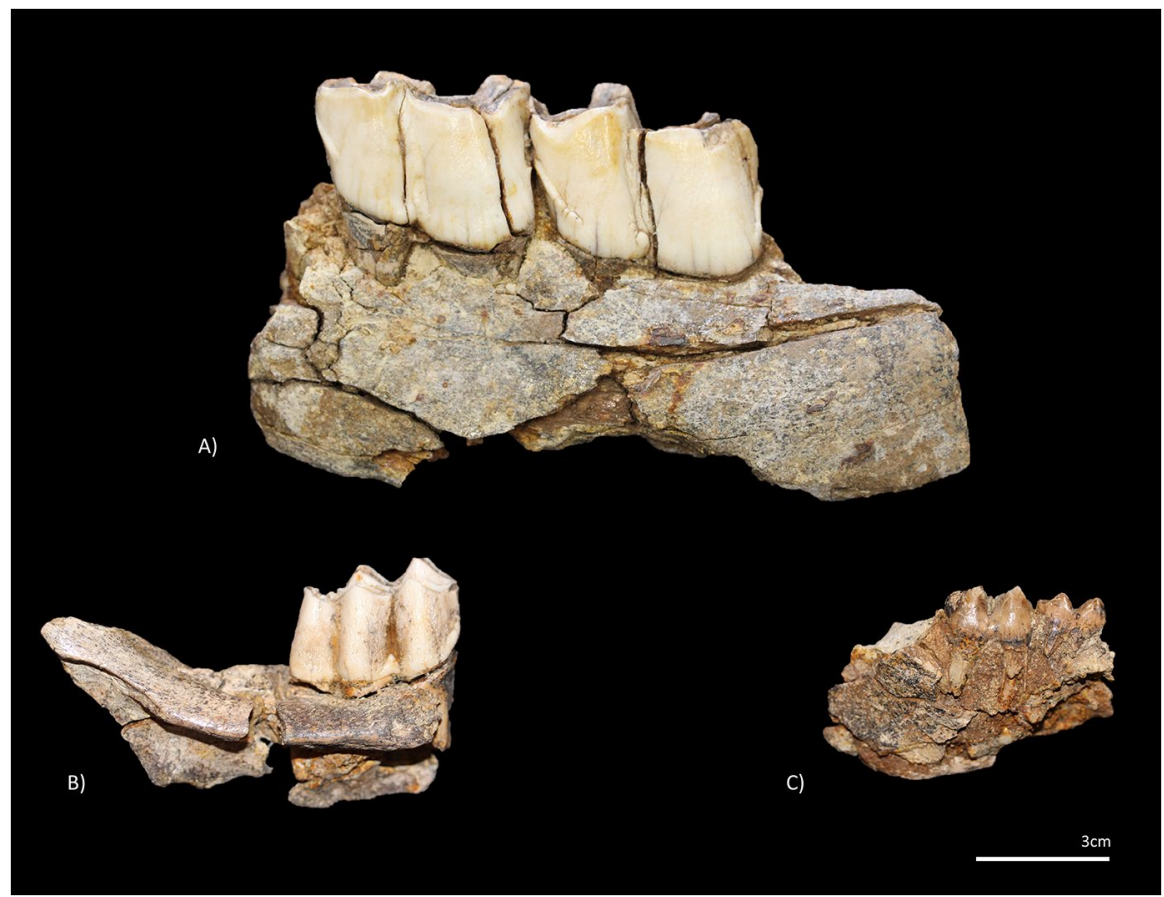

Fig. 4 Jaws recovered from Isernia La Pineta, 3 coll, with evidence of bone surface alteration belonging to a rhinoceros (A), deer (B), and suid (C) materils hosted at UNIFE

Carnivore activity has been documented through the identification of scores and pits $(n=44 ; 0.8 \%)$. Limb bones have the highest number of tooth marks $(n=15)$, particularly the shafts $(n=12)$, although these marks have also been documented on flat and articular bones. A metric comparison of the tooth marks has allowed us to identify the intervention of at least one large carnivore on the assemblage. In one case, it has been possible to identify the co-occurrence of both hominins and carnivores on the same carcass, where carnivore tooth marks and cut marks were both identified on the proximal shaft of a bison tibia.

Analyses of the skeletal representation reveal a pattern in which the disappearance of the less dense elements (e.g., axial skeleton and epiphyses of limb bones) exhibits different trends. The axial-to-appendicular ratio shows a relatively high survival rate for the axial elements (0.76). The epiphysis-to-shaft ratio shows a high disappearance rate of epiphyses in level 3 coll (0.12), while an evaluation of epiphysis survival based on the percentage of change of the minimum number of elements (MNE) shows values close to $50 \%$ for all sizes. These data point to a moderate level of disappearance of the less dense elements in the assemblage, which has been correlated with a low to moderately competitive context (Pineda et al., 2020). 


\section{Interpretation of the Site}

The reconstructed environment of Isernia La Pineta has been described as an open, arboreal steppe landscape, and the best-represented fauna (e.g., Palaeoloxodon antiquus and Stephanorhinus hundsheimensis) and flora (identified through pollen studies, predominated by herbaceous plants (Arobba et al., 2004; Peretto et al., 2004; Sala, 1996)) are typical of these biomes. The identification of aquatic (e.g., Hippopotamus antiquus and Arvícola cantianus) and riparian (e.g., Bison schoetensacki, Sus scrofa, and Quercus sp.) species suggests the presence of ponded water and deciduous forests in the surrounding area (Arobba et al., 2004; Peretto et al., 2004; Pineda et al., 2020).

The traditional interpretation of the archeosurfaces and paleosols suggests the accumulations had an anthropic origin (Anconetani, 1996a, b; Anconetani \& Peretto, 1996; Thun-Hohenstein et al., 2003; 2009; Peretto et al., 2004). They are characterized by the predominance of cranial and appendicular bison elements (attributed to a differential transport of the carcasses), with a prevalence of adult and sub-adult individuals and abundant anthropic breakage. A large Middle Pleistocene stone tool assemblage has also been described, made mainly of flint and limestone and with complete chaînes opératoires that suggest in situ knapping (Peretto et al., 2004, 2015). Use-wear studies of several flakes have indicated butchery activities (Vergès, 2002).

According to the interpretations of the team leading the excavation work, human groups would have systematically hunted, transported, and consumed the carcasses, although opportunistic scavenging of some specimens is not ruled out (Peretto et al., 2004; Thun Hohenstein et al., 2009). However, there has always been debate about the anthropic origin of these accumulations (Brugal, 1999). This researcher stated that the accumulations could have been produced by lions and that humans had secondary access to them. Indeed, the poor preservation of the bone surfaces made it difficult to test these hypotheses.

Recently, a new sequencing model of hominin and carnivore access to the carcasses at level 3 coll has been proposed. The modifications generated by these agents on the bone surfaces (cut marks and tooth marks) in both cases indicate primary access to different carcasses. According to this data, the accumulation would have formed through a succession of independent events produced by both hominins and carnivores (Pineda et al., 2020).

\section{Torralba (Soria, Spain)}

The Torralba site is located in Torralba del Moral (Soria, Spain), on the dividing line between the Duero, Tajo, and Ebro river basins. This site has been excavated intermittently since the beginning of the twentieth century, first by Enrique de Aguilera y Gamboa, XVII Marquis of Cerralbo, between 1909 and 1913 (Aguilera y Gamboa, 1913), and later by a team headed by Howell, between 1961 and 1963 (Howell et al., 1962). In the 1990s, an area near that originally excavated by the Marqués de Cerralbo was excavated, in a project focusing on the neighboring site of Ambrona 
(Santonja et al., 2005). Currently, scheduled excavations have been resumed at both sites.

The only detailed stratigraphy of the site was logged during the time when Howell was excavating, and involves a N-S section through the site (Butzer, 1965). According to Santonja et al. (2014), the majority of the materials recovered in the different excavation phases at Torralba come from a 1-m thick deposit comprising gray sands interspersed with angular and sub-angular carbonate gravel facies. The most recent chronology dates Torralba as late Middle Pleistocene, around $200 \mathrm{Ka}$ (Santonja et al., 2014).

\section{The Torralba Archaeological Record}

In Villa's (1990) taphonomic review of the materials from this site, she noted a bias in the Torralba record, with a loss of the smallest remains (both bone and stone tools), due to the absence of a systematic screening during excavation work. Added to this are the problems deriving from the dispersion of materials, which were deposited in different institutions and with no standardized record. Results summarized in this manuscript become from 3345 faunal remains studied by Pineda and Saladié (2019), deposited in the Museo Numantino de Soria (MNS), the Museo Arqueológico Nacional de Madrid (MAN), and the Museo Nacional de Ciencias Naturales de Madrid (MNCN-CSIC).

A third problem deriving from the study of the collections that were done during the early years of archaeological and paleontological research is the absence of data on the origin of part of the materials. The level from which materials most likely derived has been determined in $55.3 \%$ of the cases and has been correlated with levels B1-B5 and B7, as described by Butzer (1965). The majority of materials assigned to a specific level are concentrated in levels B1 (656), B2 (626), B4 (415), and B5 (143). The remainder of the material (1597 elements; $44.7 \%$ ) could not be attributed to a specific level, and $7.3 \%$ of the sample could only be attributed to the excavation period (Cerralbo period or Howell period), with the rest being considered material of indeterminate origin.

Elephant (Palaeoloxodon antiquus), horse (Equus caballus (torralbae)), bovid (Bos antiquus), and rhinoceros (Stephanorhinus hemitoechus) are the predominant taxa in the studied assemblage (Adam, 1961; Aguilera y Gamboa, 1913, Aguirre, 2005; Fuentes, 2005; Howell et al., 1963; Santonja et al., 2014; Sesé \& Soto, 2005) (Table 6).

Bone fragments represent the $\sim 88-90 \%$ of the material in each level. In general, the bone surfaces are poorly preserved, as a consequence of processes such as weathering (affecting about $80 \%$ of the sample), abrasion (around 50\%) and, to a lesser extent, trampling and chemical alteration of the surfaces (approximately 10\%) (Table 3) (Fig. 5). The correlation of the mineral density to the \%MAU suggests a positive and statistically significant correlation for the medium-sized animals of levels B2 and B4 and the large animals of levels B1, B2, and B4. The correlation is negative in the case of the large animals of level B5, but lacking statistical significance $(>0.05)$ (Table 4). 
Evidence of anthropic activity is limited to four cut-marked remains: on a large radius on the level B2 and on three remains without level assignation: a horse jaw, a bovid tibia, and an elephant fragment. During the studies of the materials carried out by Howell et al., four bone fragments were identified as tools (Howell et al., 1963). However, in a later review of the materials, Domínguez-Rodrigo (2005) rejected the anthropic origin and attributed their morphology to hyena activity. In Torralba, the activity of carnivores has been documented through tooth marks on 78 remains in the different levels, ranging between 0.7 and 4.3 in each one. In addition, other modifications have been recorded, such as pitting on a horse metatarsal and furrowing on 13 remains, including a bovid humerus and an elephant phalanx. A metric analysis of the tooth marks, added to the other evidence, has allowed us to infer the participation of at least one large carnivore as a modifying agent.

The analysis of the skeletal representation patterns of the different levels has allowed us to associate the human presence to times of low or low-to-moderate inferred competition, where the less dense elements (such as the epiphyses of the limb bones and axial elements) are well represented.

The excavations conducted by the Marqués de Cerralbo and Howell also provided a high number of Acheulean-type lithic remains (Aguilera y Gamboa, 1913, Howell et al., 1963), which have been studied in various works (Carbonell et al., 1987; González Echegaray \& Freeman, 1998; Sánchez-Cervera et al., 2015; Santonja \& Villa, 1990). From the Cerralbo period, wood remains were recovered, studied by Howell and his team, who highlighted the presence of traces of anthropic origin in nine of them, as well as evidence of the use of fire (Howell, 1966; Howell et al., 1962). However, a recent review carried out by Postigo-Mijarra et al. (2017), has rejected any evidence of the anthropic processing of these remains, taxonomically identified as Pinus cf. sylvestris.

\section{Interpretation of the Site}

As a consequence of the predominance of elephant remains and their importance in the reconstruction of hominin behavior, the majority of zooarchaeological and taphonomic studies have focused on these taxa (Binford, 1981, 1987; DomínguezRodrigo, 1998; Haynes, 1991; Klein, 1987; Shipman \& Rose, 1983a; Villa et al., 2005; Yravedra, 2000). The initial interpretations of the site pointed to hominins as accumulators of proboscidean carcasses (Aguilera y Gamboa, 1913), going as far as to describe complex strategies for hunting these animals, which could have been led to mudflats where they would have been killed, disarticulated, and defleshed for consumption (Biberson, 1968; Freeman \& Howell, 1982; Howell, 1966; Howell et al., 1962).

The interpretations expounded in the 1980s assigned hominins a much more minor role as accumulators and modifiers of the proboscidean carcasses, mainly due to the almost total absence of evidence of anthropic processing (Binford, 1981, 1987; Domínguez-Rodrigo, 1998; Klein, 1987; Pineda \& Saladié, 2019; Shipman \& Rose, 1983a; Villa, 1990; Villa et al., 2005; Yravedra, 2000). The other taxa 


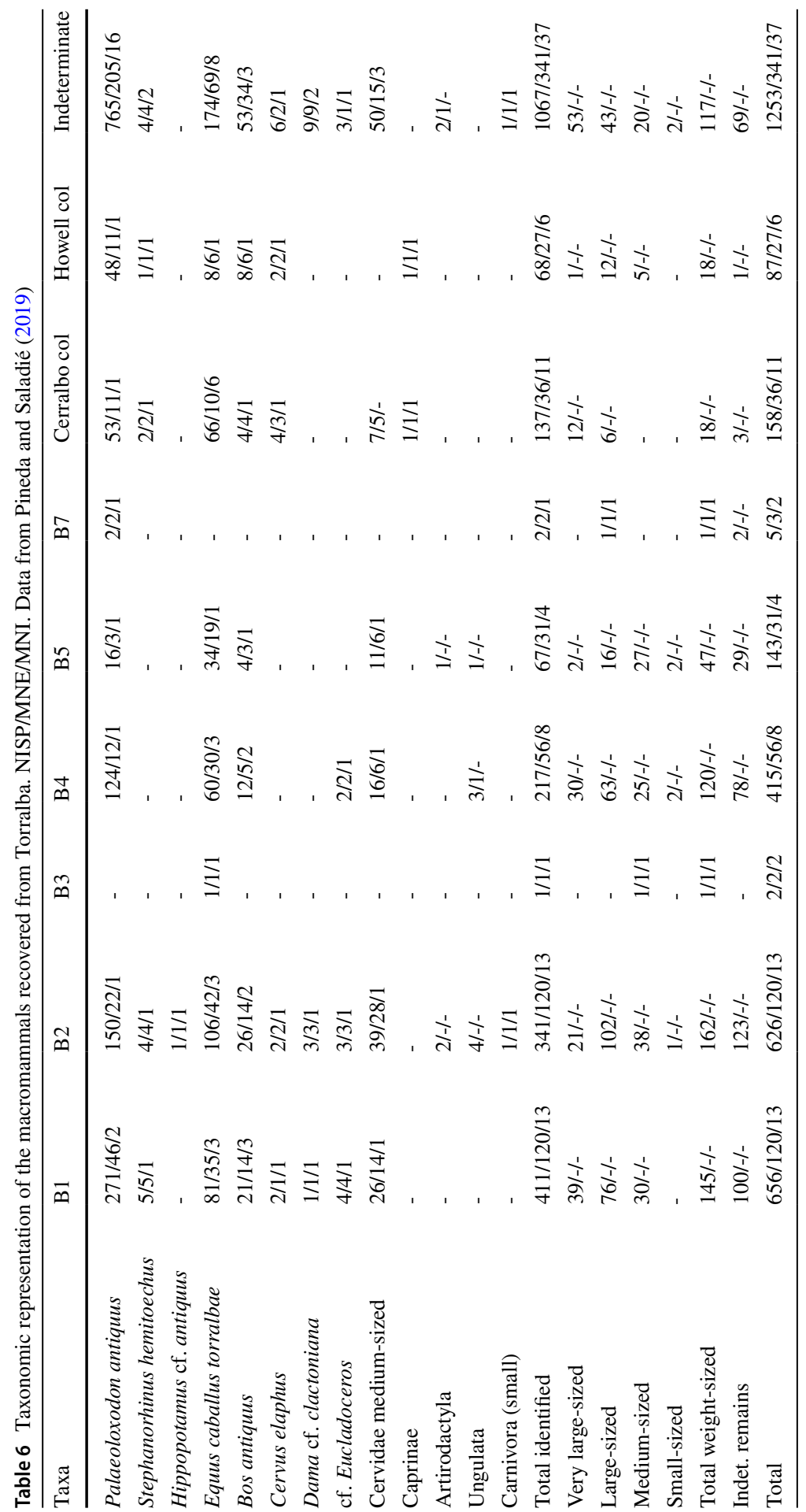




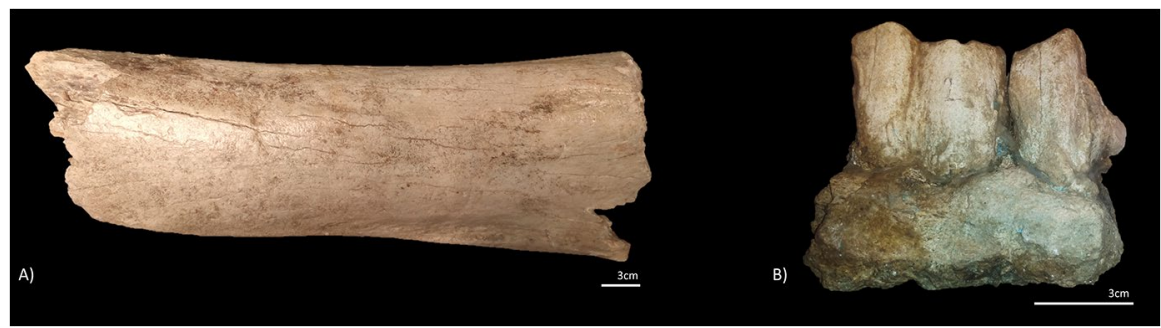

Fig. 5 Remains recovered from Torralba with evidence of bone surface alteration: (A) elephant limb bone fragment (hosted at MNCN-CSIC); (B) rhinoceros jaw (hosted at MNS)

(hippopotamus, horse, bovid, deer, and goat) also show little evidence of anthropic processing (Pineda \& Saladié, 2019).

The sedimentological context described for Torralba corresponds to an open-air space on a lake shore (Butzer, 1965). Elephants would have died on the shores of this paleolake, as suggested by various ethological studies (Haynes, 1988, 1991, 2005), in an environment in which there would be resources of various kinds of interest to hominins and other predators. The recent review of the assemblage allows us to propose a scenario in the form of a spatial palimpsest to which stone tools are associated, although not necessarily related to the faunal remains. In this panorama, an analysis of the anatomical profiles has evidenced a scenario of low-to-moderate competition between predators for the resources, with low levels of anthropic and carnivore activity being documented. However, the poor preservation of the bone surfaces could have obliterated pre-existing modifications, so any interpretations based on bone surface modifications should be taken with caution.

\section{Discussion}

The archaeological sites of Barranc de la Boella, Isernia La Pineta, and Torralba are open-air sites with similarities in the composition of the assemblages and the taphonomic features (Table 7), which have contributed to broadening our knowledge of the activities that hominin groups developed in open spaces in different phases of the Lower Paleolithic. Paleoenvironmental scenarios with common characteristics have been described for these assemblages, such as their locations in fluvial-deltaic zones (Arobba et al., 2004; Butzer, 1965; Peretto et al., 2004; Santonja et al., 2014; Vallverdú et al., 2014b), contexts characterized by the availability of resources of interest to both animal and hominin communities.

In these contexts, evidences of the presence and the activity of both carnivores and hominins are usually more abundant than their remains. May be the most explicative case is the level II.3 of La Mina, a hyena latrine composed almost exclusively by coprolites, hyenas become the main accumulator (defecator) agent of the assemblage (Pineda et al., 2017a). In fact, the activity of hyena was inferred in the sites, although no remains belonging to this taxon have been recovered so far (Pineda 
Table 7 Comparison of the main features of the assemblages studied. Black cells represent presence of the feature, while white cell represents the absence

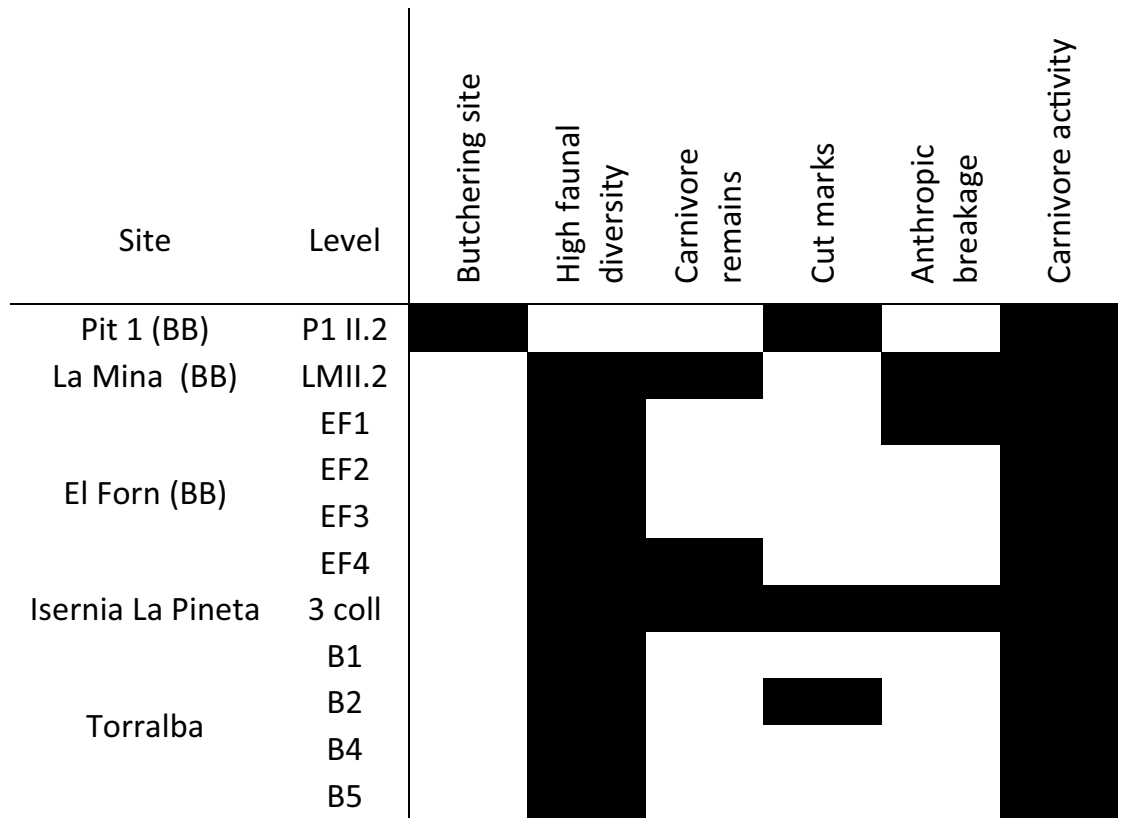

et al., 2017b; Vallverdú et al., 2014a, 2014b). The presence of carnivores in these paleoecological contexts is indicative of the availability of resources of interest, such as the existence of prey and water (Domínguez-Rodrigo \& Barba, 2007b; Egeland, 2008, 2014).

In the case of hominin groups, in addition, there are other resources such as vegetation and the availability of raw materials for tool making manufacture of tools (Domínguez-Rodrigo et al., 2007; Egeland, 2008, 2014). At all the sites, lithic remains are frequent and show the presence of human groups in the territory (Mosquera et al., 2015, 2016; Peretto et al., 2015; Sánchez-Cervera et al., 2015), although the evidence of their action on the animal carcasses is scarce at all of the sites. This situation reflects a common characteristic of assemblages from open-space sites: the recovery of lithic industry and faunal remains, with little or no evidence of anthropic processing (e.g., Shipman \& Rose, 1983a; Díez Fernández-Lomana et al., 1997; Villa et al., 2005; Egeland, 2007, 2008; Egeland \& Domínguez-Rodrigo, 2008; Espigares et al., 2013). Additionally, in this type of assemblage, bone surface conservation problems are frequently documented (Egeland, 2007, 2008; Egeland \& Domínguez-Rodrigo, 2008; Yravedra et al., 2016), including in the Barranc de la Boella pits (Pineda et al., 2014, 2015; 2017b; Mosquera et al., 2015), at Isernia La Pineta (Díez Fernández-Lomana et al., 1997; Malerba et al., 2000; Pineda et al., 2020), and Torralba (Binford, 1981; Pineda \& Saladié, 2019; Shipman \& Rose, 1983a, b; Villa et al., 2005; Yravedra, 2000). Despite the chronological distance separating these assemblages, they share a series of common taphonomic features: (a) they comprise mainly large and medium-sized ungulates and megaherbivores; 
(b) the bone surfaces show little or no evidence of anthropic processing; and (c) carnivore activity is documented despite the scarcity of their remains.

Interpreting the relationship between the faunal remains and the activities of human groups can be extremely complex and, at times, even lead to contradictory interpretations. Perhaps one of the best examples of this is Ambrona, a site near Torralba that has a similar history of interventions. At Ambrona (350-400 Ka), the predominant taxon is the elephant, and the site was described as an elephant hunting ground for much of the twentieth century (Howell et al., 1963; 1995; Howell, 1966), until the relationship between the faunal remains and stone tools began to be questioned, beginning in the 1980s (Binford, 1981, 1987; Domínguez-Rodrigo, 1998; Klein, 1987; Shipman \& Rose, 1983b; Villa et al., 2005; Yravedra, 2000). As previously mentioned, the elephant is also the predominant taxon in the faunal record of the Torralba site, although there, evidence of human intervention on the remains is scarce and the processing of these taxa has also been questioned since the 1980s (Binford, 1981, 1987; Domínguez-Rodrigo, 1998; Klein, 1987; Pineda \& Saladié, 2019; Shipman \& Rose, 1983a; Villa, 1990; Villa et al., 2005; Yravedra, 2000).

Primary access of Pleistocene hominins to large amounts of meat, at least since the Early Pleistocene, is proven (Domínguez-Rodrigo et al., 2002; Saladié et al., 2011, 2014; Espigares et al., 2013; Mosquera et al., 2015). Level II.2 of Pit 1, at Barranc de la Boella, shows a clear spatial relationship between the stone tools and the remains of Mammuthus meridionalis, and this link is supported by the use-wear study of some flakes, which suggests their use for defleshing, despite the poor conservation of bone surfaces and the scarcity of taphonomic signs of anthropic processing (Mosquera et al., 2015). This evidence has led to the location being classified as a butchering site where a mammoth carcass was processed by the hominin groups (Isaac, 1978). On the Iberian Peninsula, this type of accumulation is abundant. Middle Pleistocene sites of Áridos 1 and Áridos 2 (Madrid) ( 384 Ka) and the Early Pleistocene site of Fuente Nueva 3 (Granada) (1.4 Ma) are open-air sites that have been similarly interpreted. At both Áridos 1 and Áridos 2, Acheulean tools were recovered associated to elephant remains (Elephas (Paleoxodon) antiquus). At Áridos 2, anthropic processing of the animals has been interpreted through some cut marks on a scapula and a rib (Yravedra et al., 2010); however, at Áridos 1 , no cut marks have been identified and the exploitation of these animals has been inferred from the spatial relationship of the materials and use-wear studies (Ollé, 2005). Likewise, at Fuente Nueva 3, Espigares et al. (2014) interpreted the exploitation of a mammoth (Mammuthus meridionalis) carcass by hominins as the primary access, followed by hyenas, based on the spatial relationship between the mammoth remains, stone tools, and hyena coprolites. No signs of anthropic activity on bone surfaces have been documented. Beyond the Iberian Peninsula, the hippopotamus/artifact sites (FxJj 3) locality of Koobi Fora (1.89-1.65 Ma), is one of the first and most paradigmatic butchering sites (Isaac, 1971). African Early Stone Age assemblages such as Olorgesailie (Kenya) (1.2-0.5 Ma), attributed to Homo erectus (Kübler et al., 2015), and the 1.4 Ma ST4 assemblage (Peninj formation, Tanzania) have also been interpreted as butchering sites, with evidence of a faunaindustry association that seems to support these interpretations. Similar interpretations have been proposed for the Homo erectus Middle Pleistocene assemblages of 
Notarchirico (Piperno \& Tagliacozzo, 2001; Moncel et al., 2020) and La Cotte de Saint Brelade (Jersey).

The almost total absence of cut marks on proboscidean or other megaherbivores is a topic widely discussed, since some researches have shown that cut marks produced during its processing could appear at low frequencies and are sometimes difficult to identify (Crader, 1983; Haynes, 1991; Haynes \& Klimowicz, 2015; Haynes et al., 2020; Villa et al., 2005). A recent experimentation conducted and published by Haynes and Krasinski (2021) has shown different strategies of exploitation of the carcasses, with different results in the bone surface modifications resulting in each case. In a satisficing carcass processing, butchers were satisfied to take tusks, largest parts of muscle masses, and skin before abandoning the carcasses, resulting in low frequencies of cut marks. However, in an extended carcass processing in which efforts are made to completely strip meat scraps remaining on the largest limb bones, cut marks could appear clearly visible on limb bone shafts (Haynes \& Krasinski, 2021). The absence of cut marks on these remains in Paleolithic contexts, as in the case of Torralba, could respond to a satisficing carcass processing, although a second factor should be taken into account: the bad preservation of bone surfaces. If the hominins at Torralba did take advantage of the biomass of these animals, unfortunately, the poor preservation of the bone surfaces will have reduced any evidence of anthropic activity on the elephant remains. Precisely for this reason, we cannot rule out the fact that these populations did not act as carcass modifying agents, as previously suggested for both this and the neighboring Ambrona site (Domínguez-Rodrigo, 1998; Shipman \& Rose, 1983b; Villa et al., 2005; Yravedra, 2000), although we can discard a leading role of the hominins in the accumulation of elephant remains in Torralba, as suggested by Shipman and Rose (1983b). In fact, despite the similarities that may exist between the compositions of the Torralba and Pit 1 faunal records, where the proboscidean is the predominant taxon at both sites, the truth is that Torralba seems to be more similar to La Mina and El Forn in regard to the limited role played by hominin groups in the accumulation of the deposits.

This type of deposit is common in the open-air archaeological record. Taphonomic reviews of various Olduvai Gorge Bed 1 localities, dated 1.8 Ma and associated to Homo habilis and Paranthropus boisei, performed in recent decades, have been focused on correctly interpreting the processes involved in the formation of these assemblages. Hypotheses indicating that water currents played an important role in the formation of assemblages at localities such as FLK Zinj, either due to the contribution or lagging of materials (Benito-Calvo \& de la Torre, 2011; de la Torre \& Benito-Calvo, 2013), have recently been questioned by Domínguez-Rodrigo, Baquedano, et al. (2019), who defend the anthropic origin of this accumulation. In contrast, for other assemblages, like FLK N3-4, FLK NN1, FLK N1-2, and FLK NN3, which were originally interpreted as anthropic accumulations (Binford, 1981; Bunn, 1986; Leakey, 1971; Potts, 1984), the taphonomic reinterpretations suggest a scarce or null role of hominins in the accumulation and formation of the deposits (Barba \& Domínguez-Rodrigo, 2007; Bunn et al., 2010; Domínguez-Rodrigo \& Barba, 2007b, c; Domínguez-Rodrigo, Mabulla, et al., 2010; Egeland et al., 2004). These locales are defined as vertically dispersed deposits and are characterized by 
the presence of both faunal and lithic remains, although the evidence of anthropic processing of the carcasses is very scarce and the fauna-industry and hominin-carnivore relationships are not necessarily proven, as the two agents may have independent taphonomic histories.

From the French site of Bois-de-Riquet, dated 1.3-1.1 Ma, an extensive lithic and faunal assemblage has been documented, where the evidence of carcass processing is limited to two cut marks on ungulate limb bones. Researchers have suggested that this could be an accumulation resulting from carnivore activity, with a very limited contribution from hominins (Bourguignon et al., 2016).

Several assemblages dated as Middle Pleistocene also fit these descriptions. The Italian site of Fontana Ranuccio (Muttoni et al., 2009; Segre \& Ascenzi, 1984) (450 Ka) presents fossil levels with Acheulean stone tools and an extensive taxonomic list in which medium and large ungulates predominate and in which human tooth related with ancient Neanderthal populations (Segre-Naldini et al., 2009; Rubini et al., 2014). To date, there are no taphonomic studies that evaluate the role of the hominin groups in the accumulation or processing of the faunal remains. In addition, the Kärlich-Seeufer site (Germany) (396-240 Ka) has an extensive lithic and faunal assemblage, with a predominance of elephant remains, but the anthropic processing of the carcasses is limited to some cut marks on elephant bones (Gaudzinski et al., 1996). At the Castel di Guido site (Italy) (327-260 Ka), a fluvial origin has been proposed for the accumulation of the remains, which included cranial fragment attributed to Homo heidelbergensis, intermingled with events of anthropic intervention on some remains (mainly horse and bovid) (Boschian and Saccà, 2010; 2015). Also in Italy, recent studies have been conducted at the abovementioned site of Notarchirico. Moncel et al. (2020) described a large lithic and faunal assemblage dating back to $700 \mathrm{Ka}$, in whsssich there is no evidence of processing or consumption by human groups. Evidence of anthropic activity is also scarce at the German site of Bilzingsleben (420-250 Ka). In this site, the existence of various accumulation processes has been proposed, with no single agent being particularly responsible (Müller \& Pasda, 2011).

As mentioned earlier, La Mina, El Forn, Isernia La Pineta, and Torralba are four assemblages that are part of this wide list of Lower Paleolithic sites in which the role of the hominins in the formation of the deposits and the processing of the carcasses seems to be scarce. Weathering becomes the main process of alteration of the bone surfaces at Isernia, El Forn, and Torralba. Its identification is indicative of a more or less prolonged exposure of the remains in the open-air (Behrensmeyer, 1978; Junod \& Pokines, 2014). "Taphonomic times" could be very different among environment, reason why the analysis of weathering does not always allow us to make inferences about the time of formation of the assemblages (Lyman, 1994; Lyman \& Fox, 1989). This premise is especially relevant if we take into account that the environmental conditions that could affect our assemblages are not comparable to those in which Behrensmeyer (1978) conducted her experiments (Amboseli Park, Kenya). In the absence of new reference works that allow us to develop more robust analogies, the presence of weathering in our assemblages allows us to infer an exposure of the remains in the open-air, but no information about periodization is determined. In a later work, Haynes and Klimowicz (2015) determined that elephant remains can 
remain on the surface for 4 decades prior being buried. In the assemblages presented in this study, similarly to those of Pit 1 (Mosquera et al., 2015), a high degree of weathering of the proboscidean remains has been documented, reflecting a prolonged exposure time for these carcasses, and inferring slow burial processes. At La Mina, on the other hand, the weathering is less intense and seen on fewer remains, suggesting the remains were exposed for less time and, therefore, a faster sedimentation process. However, in this group, lixiviation is the main process that has altered the bone surfaces and the striae found on these, obliterating the diagnostic criteria used to identify them (Domínguez-Rodrigo et al. 2019a; 2017). The problem at Isernia involves the high number of striations identified on the bone surfaces (around $30 \%$ of the sample) due to friction with the sedimentary particles of volcanic origin comprising the deposit. These have altered the surfaces and make it difficult to distinguish between the cut marks and the new striations of taphonomic origin (Anconetani et al., 1996; Malerba et al., 2000; Thun Hohenstein et al., 2004). Although various processes have been described that would have acted on the assemblages studied, they all exhibit poorly preserved bone surfaces, altered pre-existing striae, and the appearance of new striae that may mimic or obliterate cut marks or other signs of anthropic origin. Domínguez-Rodrigo, Mabulla, et al. (2010) suggested that the identification of human-produced modifications should be limited to assemblages or remains with well-preserved surfaces, to avoid incorrect identification and erroneous behavioral interpretations.

Poor preservation could explain why there is so little evidence of anthropic cut marks on bone surfaces in the assemblages studied. A multiple linear regression analysis has been carried out in order to check if the number of cut marks preserved in the studied assemblages has been affected by the action of four variables: presence of weathering, water abrasion, trampling, and chemical corrosion on the bone surfaces (Table 8). The regression statistics show a high multiple correlation coefficient $(r=0.990 .1973)$, including the adjusted $R^{\wedge} 2(0.9678886)$, which takes into account the sample size and the number of variables. The analysis of variance shows a high, positive, and statistically significance $(F=76.3 ; p<0.05)$. Finally, the analysis of the coefficients of each variable shows that three of the four variables analyzed (weathering, water abrasion, and chemical corrosion) have a negative $T$ value, which means that their presence negatively affects the number of preserved cut marks.

However, this in no way implies the presence of cut marks that were subsequently obliterated (Domínguez-Rodrigo, Mabulla, et al., 2010). In fact, carnivore activity has been documented in these assemblages in form of tooth marks on the bone surfaces. Multiple linear regression analysis has also been carried out to test how these variables affect tooth-mark survival (Table 9). The multiple correlation coefficient is lower than in the case of cut marks $(r=0.895746375)$, especially if we take into account the adjusted $R^{\wedge} 2(0.670602615)$, which takes into account the sample size and the number of variables. The analysis of variance shows a very low significance $(F=6.08 ; p<0.05)$. A possible explanation for the major documentation of tooth marks rather than cut marks, then, would be that the first one can be deeper, and some of them could survive to alterations better than cut marks. An alternative explanation would be that cut marks can be easily confused with other nonanthropogenic striae, such as trampling marks, and even more in the case of altered 

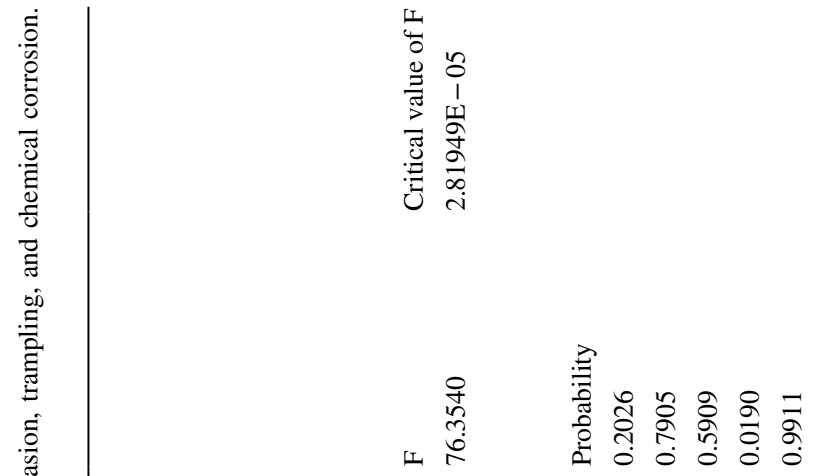

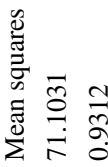

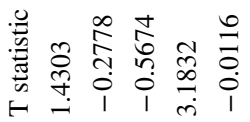

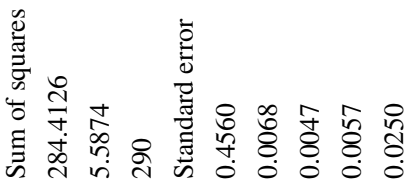

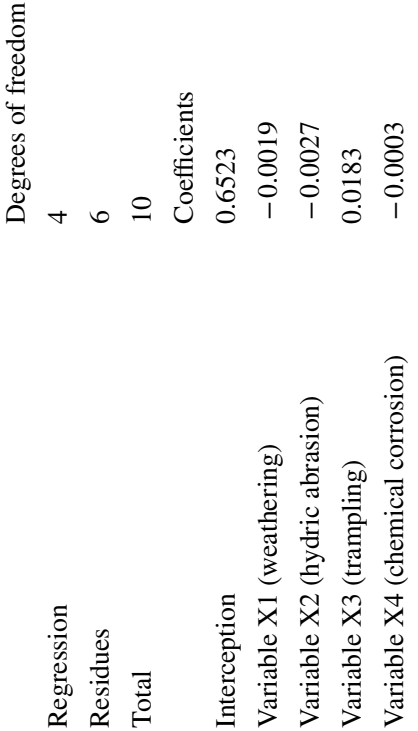




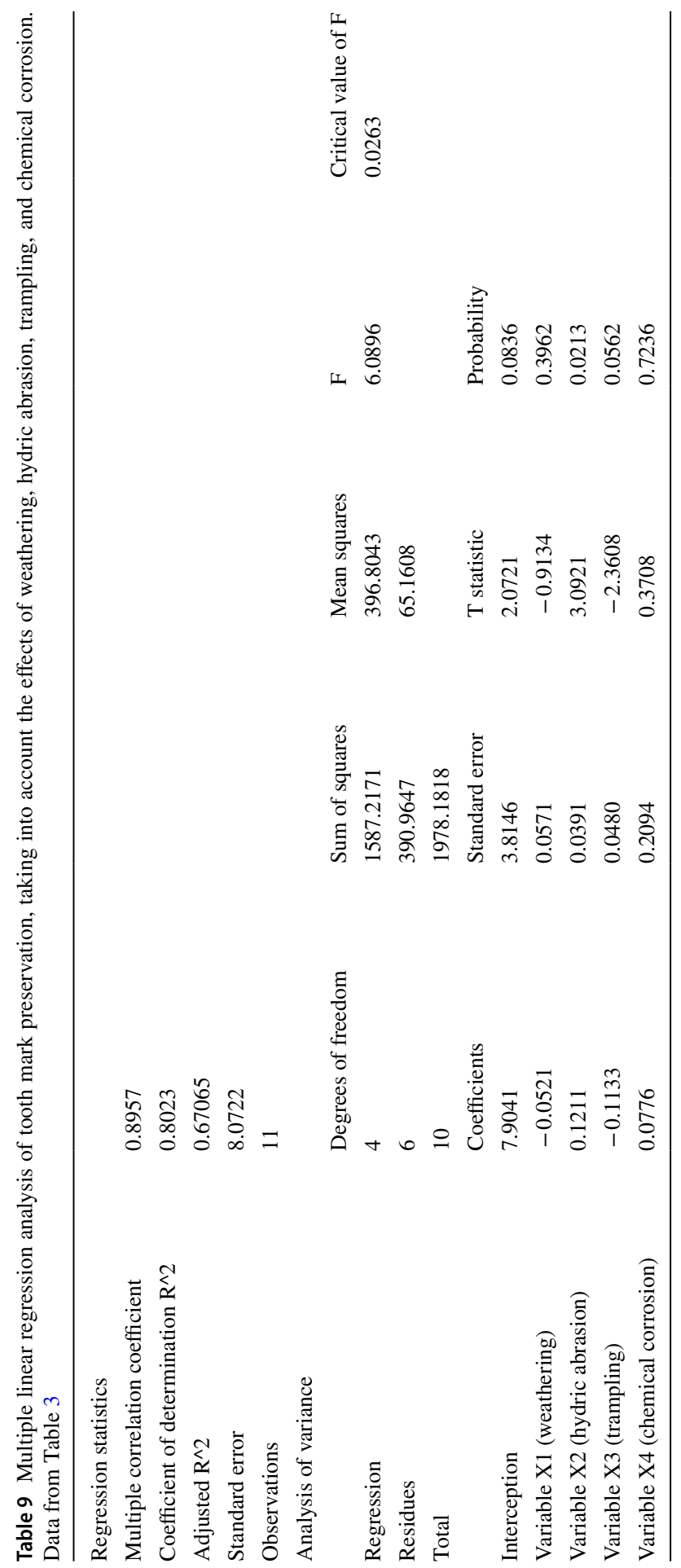


surfaces (Domínguez-Rodrigo, Mabulla, et al., 2010; Pineda et al., 2014, 2019), resulting in a lower number of cut marks identified. A third explanation for the better documentation of the tooth marks would be that hominin groups never acted on the faunal carcasses (or, at least, over a major part of them), which is why evidence of anthropogenic activity in the form of modifications to bone surfaces was never present. In recent taphonomic reviews of these assemblages, we have proposed that anthropic evidence could reflect the transit of hominin groups through these spaces, without interaction with faunal remains recovered (Pineda \& Saladié, 2019; Pineda et al., 2017b, 2020). This hypothesis cannot be ruled out, especially if we take into account the fact that there is other evidence indicating the access of human groups to these resources. Use-wear studies of the lithic tools evidence defleshing activities at Isernia La Pineta (Vergès, 2002), as also documented at Pit 1 (Mosquera et al., 2015).

Green breakage is predominant in almost all the levels studied, with values close to or exceeding $50 \%$. This kind of breakage is produced by biological agents (hominins and bone-cracking carnivores) in order to access the marrow. In itself, green breakage does not allow us to distinguish between the different biological agents that could have been responsible for fracturing in our assemblages, although it does indicate the existence of nutritional resources of interest to the agents that inhabited these environments.

Only when the existence of diagnostic criteria such as percussion pits is documented, is it possible to attribute the breakage to hominins (Blumenschine \& Selvaggio, 1988; Pickering \& Egeland, 2006). At Isernia, anthropic breakage is the main hominin carcass-processing sign throughout the entire sequence, in which cut marks are scarce (Anconetani \& Peretto, 1996; Thun Hohenstein et al., 2005, 2009; Pineda et al., 2020). Through the association of tooth marks and anthropic breakage, and due to the scarcity of cut marks, secondary access of human groups to at least a portion of the carcasses was previously proposed for Isernia (Thun Hohenstein et al., 2009). In level 3 coll, tooth marks are seen primarily on the mid-shafts of the limb bones, although they have also been documented on ribs (Pineda et al., 2020). These locations respond to a pattern of primary access by carnivores (Blumenschine, 1987). Cut marks on mid-shafts (Pineda et al., 2020) also suggest primary access of hominins to the carcasses (Capaldo, 1997, 1998; Selvaggio, 1994). For this reason, we consider it plausible that the two agents accessed different carcasses independently (Pineda et al., 2020). Poor preservation of bone surfaces could mask evidence of human intervention, so, while we cannot rule out possible scavenging events, support for this idea based on the absence of cut marks should be treated with caution in assemblages with poorly preserved bone surfaces, such as Isernia, where the absence of these modifications could simply be the result of taphonomic processes. At La Mina and El Forn, anthropic breakage, although scarce, is present. This is not the case at Torralba, where no clear signs of anthropic fracturing of the carcasses have been found.

Our deposits are characterized by a mixture of spatially segregated episodes, in which temporal relationships are blurred and difficult to individualize, according to the Bailey's (2008) description of spatial palimpsest. In these depositional contexts, the spatio-temporal relationships of the aggregates that compose them are 
blurred and difficult to establish, reflecting events of different natures and ecological compositions.

The use of anatomical profiles has proved a useful tool for reconstructing the paleoecological environments inhabited by Pleistocene hominins through an analogy with current naturalistic environments. These have been effective for inferring, for example, levels of ravaging produced by bone-crushing carnivores (DomínguezRodrigo \& Organista, 2007; Faith et al., 2007; Egeland, 2008). The greater the abundance of carnivores competing for the same resource, the greater the ravaging of the carcasses (Faith \& Behrensmeyer, 2006). This, in turn, can be correlated with increased competition in the environment (Domínguez-Rodrigo \& Organista, 2007). Factors like nutritional stress can cause carnivores to produce high levels of ravaging, even in low-competition contexts, so the relationship between ravaging and paleoecological trophic dynamics requires future in-depth studies, and any extrapolations should be carried out with caution (Domínguez-Rodrigo \& Organista, 2007). Furthermore, these contexts involve an additional actor, absent in actualist contexts: hominin populations. The highest levels of inferred competition have been documented at La Mina. One of the hypotheses considered is that this was due to the low availability of meat resources. However, the presence of lithic (Mosquera et al., 2016) and taphonomic signs produced by carnivores would indicate the cooccurrence of these actors in the same space, indicative of the existence of resources of interest to both actors (hominins and carnivores) (Egeland, 2014). The abundance of carnivores and the consequent increase in competition levels in Early and Middle Pleistocene environments were part of the daily life of these groups; indeed, factors such as the availability of resources would have had greater weight in the choice of habitat than any competition with other predators (Egeland, 2014). At El Forn, Isernia La Pineta, and Torralba, the levels of inferred competition are moderate or low, although the presence of human groups infers the existence of foraging practices in these environments. Despite having had different taphonomic histories, the studied assemblages share certain common features that reflect the degree of similarity in the mode of deposition of the remains and the use of these open-air spaces by hominins at different times during the Lower Paleolithic.

\section{Conclusions}

A commonly identified problem in open-air Plio-Pleistocene osteological assemblages is the poor preservation of bone surfaces as a result of the multiple agents and processes that can act on these. As a consequence of this action, the assemblages tend to present little or no evidence of anthropic activity, hindering zooarchaeological inferences related to hominin access to animal carcasses or the use of these spaces. At La Mina and El Forn sites, hominin activity seems to be related with foraging activities, not necessary linked to the exploitation of faunal carcasses. At Isernia la Pineta, evidences of faunal exploitation are documented and the site has been recently interpreted as a succession of multiple independent events in which hominin acted as accumulator/modifier agent in, at least, some cases. Finally, evidences identified in the faunal remains studied from Torralba suggest a scarce 
relationship between faunal and stone tools. In fact, La Mina, El Forn, Isernia La Pineta, and Torralba are four assemblages from the Lower Paleolithic characterized by poorly preserved bone surfaces, where evidence of carcass processing is scarce and, in many cases, limited to anthropic breakage. The lithic industry is the main element identifying the presence of hominin groups. The total or almost total absence of cut marks could be related to the alteration of the bone surfaces, although their absence in origin cannot be ruled out, since hominins may have carried out foraging activities in these environments, not necessarily linked to animal carcass exploitation. In this scenario, taphonomic studies have been conducted using various proxies, including the use of anatomical profiles, which is presented as a useful tool for reconstructing the paleoecological environments inhabited by hominins and enabling inferences to be made about the levels of competition among large predators. The assemblages reflect the degree of similarity between the mode of deposition of the remains and the use of these open-air spaces by hominins at different times during the Lower Paleolithic.

Acknowledgements Antonio Pineda is supported by the Spanish Ministry of Science and Innovation (FJC2019-040804-I, Subprograma Juan de la Cierva-Formación). Financial support was provided by the Spanish Ministerio de Ciencia, Investigación y Universidades (PGC2018-093925-B-C32/MICIU) and the Generalitat de Catalunya, AGAUR agency, funded project 2017 SGR-1040. The authors wish to thank the suggestions of Jessica C. Thompson and two anonymous reviewers for their valuable comments and suggestions that help us to improve the manuscript. The Institut Català de Paleoecologia Humana i Evolució Social (IPHES-CERCA) has received financial support from the Spanish Ministry of Science and Innovation through the "María de Maeztu" program for Units of Excellence (CEX2019-000945-M).

Funding Open Access funding provided thanks to the CRUE-CSIC agreement with Springer Nature.

Open Access This article is licensed under a Creative Commons Attribution 4.0 International License, which permits use, sharing, adaptation, distribution and reproduction in any medium or format, as long as you give appropriate credit to the original author(s) and the source, provide a link to the Creative Commons licence, and indicate if changes were made. The images or other third party material in this article are included in the article's Creative Commons licence, unless indicated otherwise in a credit line to the material. If material is not included in the article's Creative Commons licence and your intended use is not permitted by statutory regulation or exceeds the permitted use, you will need to obtain permission directly from the copyright holder. To view a copy of this licence, visit http://creativecommons.org/licen ses/by/4.0/.

\section{References}

Adam, K. D. (1961). Die Bedeutung dre Pleistozänen Säugetier-Faunen Mitteleuropas für die Geschichte des Eiszeitalters. Stuttgarter Beiträge Zur Naturkd., 78, 1-34.

Aguilera y Gamboa, E. (1913). Torralba, la plus ancienne station humaine de l'Europe?. In: Congres d'Anthropologie et d'Archéologie Préhistorique. ComptesRendues XIVe session, 1912: 277-290.

Aguirre, E. (2005). Torralba y Ambrona. Un siglo de encuentros. In: Los Yacimientos Paleolíticos de Ambrona y Torralba (Soria). Zona Arqueológica, Museo Arqueológico Regional de Madrid. 40-77.

Anconetani, P. (1996). Lo studio archeozoologico del sito di Isernia La Pineta. In: Peretto, C. (Ed.): I reperti paleontologici del giacimento paleolitico di Isernia La Pineta, l'Uomo e l'ambiente. Istituto Regionale per gli Studi Storici del Molise "V. Cuoco” Isernia, Cosmo Iannone Editore: 87-186. 
Anconetani, P. Peretto, C . (1996). La fratturazione intenzionale della ossa lunghe e della mandibola come índice di attività umana nel sito di Isernia La Pineta. In: Peretto, C. (Ed.). I reperti paleontologici del giacimento paleolitico di Isernia La Pineta, l'Uomo e l'ambiente. Istituto Regionale per gli Studi Storici del Molise "V. Cuoco" Isernia, Cosmo Iannone Editore: 453-530.

Anconetani, P., Malerba, G., Giacobini, G. (1996). Studio micromorfologico di superficie dei reperti faunistici di Isernia La Pineta. Considerazione tafonomiche. In: Peretto, C. (Ed.): I reperti paleontologici del giacimento paleolitico di Isernia La Pineta, l'Uomo e l'ambiente. Istituto Regionale per gli Studi Storici del Molise "V. Cuoco" Isernia, Cosmo Iannone Editore, pp. 53-86.

Andrews, P., \& Cook, J. (1985). Natural modifications to bones in a temperate setting. Man, 20, 675-691.

Andrews, P. (1990). Owls, caves and fossils: Predation, preservation and accumulation of small mammal bones in caves, with an analysis of the Pleistocene cave faunas from Westbury-Sub-Mendip, Somerset, U.K. University of Chicago Press.

Arobba, D. Boscato, P. Boschian, G. Falgueres, Ch, asani, L. Peretto, C. Sala, B.,Thun-Hohenstein, U. Tozzi, C. (2004). Paleoenvironmental analysis Collegium Antropologicum 28:5-21.

Aslan, A., \& Behrensmeyer, A. (1986). Taphonomy and time resolution of bone assemblages in a contemporary fluvial system; the East Fork River, Wyoming. Palaios, 11, 411-421.

Bailey, G. (2008). Time perspectivism: Origin and consequences. In S. Holdaway \& L. Wandsnider (Eds.), Time in Archaeology: Time Perspectivism Revisited (pp. 13-30). University Press.

Ballatore, M., \& Breda, M. (2013). Stephanorhinus hundsheimensis (Rhinocerontidae, Mammalia) teeth from the early Middle Pleistocene of Isernia La Pineta (Molise, Italy) and comparison with coeval British material. Quaternary International, 302, 169-183. https://doi.org/10.1016/j.quaint.2013. 02.002

Barba, R., \& Domínguez-Rodrigo, M. (2007). FLK North North 1: "living floor" or natural accumulation? In M. Domínguez-Rodrigo, R. Barba, \& C. P. Egeland (Eds.), Deconstructing Olduvai: A Taphonomic Study of the Bed I Sites (pp. 217-229). Springer.

Behrensmeyer, A. (1975). The taphonomy and paleoecology of Plio-Pleistocene vertebrate assemblages east of Lake Rudolf, Kenya. Bulletin of the Museum of Comparative Zoology at Harvard College., $146,476-578$.

Behrensmeyer, A. (1978). Taphonomic and ecologic information from bone weathering. Paleobiology, 4, $150-162$.

Behrensmeyer, A. K., Gordon, K. D., \& Yanagi, G. T. (1986). Trampling as a cause of bone surface damage and pseudo-cutmarks. Nature, 319, 768-771.

Behrensmeyer, A. K., Gordon, K. D., \& Yanagi, G. T. (1989). Nonhuman bone modification in Miocene fossils from Pakistan. In R. Bonnichsen \& M. H. Sorg (Eds.), Bone Modification (pp. 90-120). University of Maine Center for the Study of the First Americans.

Biberson, P. (1968). Les gisements acheuléens de Torralba et Ambrona (Espagne) Nouvelles Précisions. Anthropologie., 72, 241-278.

Binford, L. R. (1981). Bones. Academic Press, Orlando.

Binford, L. R. (1983). In pursuit of the past. Thames and Hudson.

Binford, L. (1987). Where there elephants hunters at Torralba?. In: Nitecki, M.H. Nitecki, D. V (Eds.), The Evolution of Human Hunting. Plenum Press, 7-105.

Blasco, R. (2008). Human consumption of tortoises at Level IV of Bolomor Cave (Valencia, Spain). Journal of Archaeological Science, 35, 2839-2848. https://doi.org/10.1016/j.jas.2008.05.013

Blasco, R., \& Fernández-Peris, J. (2009). Middle Pleistocene bird consumption at Level XI of Bolomor Cave (Valencia, Spain). Journal of Archaeological Science, 36, 2213-2223. https://doi.org/10. 1016/j.jas.2009.06.006

Blasco, R., Rosell, J., Smith, K. T., Maul, C., Sañudo, P., Barkai, R., \& Gopher, A. (2016). Tortoises as a dietary supplement: A view from the Middle Pleistocene site of Qesem Cave, Israel. Quaternary Science Reviews, 133, 165-182. https://doi.org/10.1016/j.quascirev.2015.12.006

Blumenschine, R. J., \& Selvaggio, M. (1988). Percussion marks on bone surfaces as a new diagnostic of hominid behavior. Nature, 333, 763-765.

Blumenschine, R. J. (1987). Characteristics of an early hominid scavenging niche. Current Anthropology $28,383-407$.

Boschian, G., \& Saccà, D. (2010). Ambiguities in human and elephant interactions? Stories of bones, sand and water from Castel di Guido (Italy). Quaternary International, 214, 3-16. https://doi.org/ 10.1016/j.quaint.2009.10.016 
Boschian, G., \& Saccà, D. (2015). In the elephant, everithing is good: Carcass use and re-use at Castel di Guido (Italy). Quaternary International, 361, 288-296. https://doi.org/10.1016/j.quaint.2014.04. 030

Bourguignon, L. C., Capdevila, J.-Y., Ivorra, R., Antoine, J., Agustí, P.-O., Barsky, J., Blain, D., Boulbes, H. A., Bruxelles, N., Claude, L., Cochard, J., Filoux, D., Firmat, A., Lozano-Fernández, C., Magniez, I., Pelletier, P., Ríos-Salazar, M., Testu, J., Valensi, A., ... L. (2016). Bois-de-Riquet (Lézignan-la-Cèbe, Hérault): A late Early Pleistocene archeological occurrence in southern France. Quaternary International, 393, 24-40. https://doi.org/10.1016/j.quaint.2015.06.037

Brain, C. K. (1981). The hunters or the hunted? University of Chicago Press, Chicago.

Breda, M., Peretto, C. T., \& Hohenstein, U. (2015). The deer from the early Middle Pleistocene site of Isernia la Pineta (Molise, Italy): Revised identifications and new remains from the last 15 years of excavation. Geological Journal, 50, 290-305. https://doi.org/10.1002/gj.2646

Brugal, J.P. (1999). Étude de populations de grands Bovidés européens: Intérêt pour la connaissance des comportements humains au Paléolithique. In: Brugal, J.P. David, F. Enloe, G.G. Jaubert, J. Le Bison: Gibier et Moyen de Subsistance des Hommes du Paléolithique aux Paléoindiens des Grandes Plaines. Actues de coloque intenational, 86-103.

Bunn, H. T. (1986). Patterns on skeletal representation and hominid subsistence activities at Olduvai Gorge, Tanzania, and Koobi Fora, Kenya. Journal of Human Evolution, 15, 673-690.

Bunn, H. T., Mabulla, A. Z. P., Domínguez-Rodrigo, M., Ashley, G. M., Barba, R., Diez-Martín, F., Remer, K., Yravedra, J., \& Baquedano, E. (2010). Was FLK North levels 1-2 a classic "living floor" of Oldowan hominins or a taphonomically complex palimpsest dominated by large carnivore feeding behavior? Quaternary Research, 74, 355-362. https://doi.org/10.1016/j.yqres.2010.06.004

Butzer, K. W. (1965). Acheulian occupation sites at Torralba and Ambrona, Spain: Their geology. Science (80-), 150, 1718-1722.

Butzer, K. W. (1982). Archaeology as human ecology. Cambridge University Press.

Cáceres, I. (2002). Tafonomía de yacimientos antrópicos en Karst. Complejo Galería (Sierra de Atapuerca, Burgos), Vanguard Cave (Gibraltar) y Abric Romaní (Capellades, Barcelona). Dpto. Historia y Geografía, Universitat Rovira i Virgili, 659.

Capaldo, S. D. (1997). Experimental determinations of carcass processing by Plio-Pleistocene hominids and carnivores at FLK 22 (Zinjanthropus), Olduvai Gorge, Tanzania. Journal of Human Evolution, 33, 555-597. https://doi.org/10.1006/jhev.1997.0150

Capaldo, S. D. (1998). Simulating the formation of dual-patterned archaeofaunal assemblages with experimental control samples. Journal of Archaeological Science, 25, 311-330. https://doi.org/10. 1006/jasc.1997.0238

Carbonell, E., Díez, J. C., Enamorado, J., \& Ortega, A. I. (1987). Análisis morfotécnico de la industria lítica de Torralba (Soria). Antropologíaletnografía, 4, 203-216.

Carr, C. (1984). The nature of organization of intrasite archaeological records and spatial analytic approaches to their investigation. Advances in Archaeological Method and Theory, 7, 103-222.

Carr, C. (1987). Dissecting intrasite artifact palimpsests using Fourier methods. Method and Theory for Activity Area Research, 19, 236-291.

Coltorti, M., \& Pieruccini, P. (2014). Guado San Nicola Acheulean site: Preliminary remarks on the litho-, morphoand pedo-stratigraphical setting. In B. Muttillo, G. Lembo, \& C. Peretto (Eds.), L'insediamento a bifacciali di Gudo San Nicola (pp. 13-24). Italia. Annali dell'Università degli Studi di Ferrara.

Coltorti, M., Cremaschi, M., Delitala, M. C., Esu, D., Fornaseri, M., McPherson, A., Nicoletti, M. V., Otterlo, R., Peretto, C., Sala, B., Schmidt, V., \& Sevink, J. (1982). Reversed magnetic polarity at Isernia La Pineta, a new lower paleolithic site in Central Italy. Nature, 300, 173-176.

Coltorti, M., Feraud, G., Marzoli, A., Peretto, C., Ton-That, T., Voinchet, P., Bahain, J.-J., Minelli, A. T., \& Hohenstein, U. (2005). New 40Ar/39Ar, stratigraphic and palaeoclimatic data on the Isernia La Pineta Lower Palaeolithic site, Molise, Italy. Quaternary International, 131, 11-22. https://doi.org/ 10.1016/j.quaint.2004.07.004

Cook, J. (1986). The application of scanning electron microscopy to taphonomic and archaeological problems. In D. A. Roe (Ed.), Studies in the Upper Palaeolithic of Britain and Northwest Europe (pp. 146-163). BAR International Series.

Courtenay, L. A., Yravedra, J., Huguet, R., Ollé, A., Aramendi, J., Mate-González, M. A., \& GonzálezAguilera, D. (2019). New taphonomic advances in 3D digital microscopy: A morphological characterization of trampling marks. Quaternary International, 517, 55-66. https://doi.org/10.1016/j. quaint.2018.12.019 
Courtenay, L. A., Huguet, R., González-Aguilera, D., \& Yravedra, J. (2020a). A hybrid geometric morphometric deep learning approach for cut and trampling mark classification. Applied Sciences, 10(150), 1-16. https://doi.org/10.3390/app10010150

Courtenay, L. A., Huguet, R., \& Yravedra, J. (2020b). Scratches and grazes: A detailed microscopic analysis of trampling phenomena. Journal of Microscopy, 277, 107-117. https://doi.org/10.1111/jmi. 12873

Crader, D. C. (1983). Recent single-carcass bone scatters and the problem of 'butchery' sites in the archaeological record. In G. Clutton-Brock \& C. Grigson (Eds.), Animals and Archaeology, Hunters and their Prey (pp. 107-141). BAR International Series.

de la Benito-Calvo, A., \& Torre, I. (2011). Analysis of orientation patterns in Olduvai Bed I assemblages using GIS techniques: Implications for site formation processes. Journal of Human Evolution, 61, 50-60. https://doi.org/10.1016/j.jhevol.2011.02.011

de la Torre, I., \& Benito-Calvo, A. (2013). Application of GIS methods to retrieve orientation patterns from imagery; a case study from Beds I and II, Olduvai Gorge (Tanzania). Journal of Archaeological Science, 40, 2446-2457. https://doi.org/10.1016/j.jas.2013.01.004

Díez Fernández-Lomana, J. C. (1993). Estudio tafonómico de los macrovertebrados de yacimientos del Pleistoceno Medio. Complutum, 4, 21-40.

Díez Fernández-Lomana, J.C. Rosell, J. Malerba, G. Thun Hohenstein, U. Giacobini, G. Peretto, C. (1997). Indagini sulle tracce di macellazione sui reperti faunistici di Isernia La Pineta (Molise, Italia): Metodologia e nuovi risultati. In: XII Cong. Ass. Antropologi Italiani . Antropologia Italiana, Palermo: 85-87.

Domínguez-Rodrigo, M. (1998). Tafonomía y ciencia Ficción: Algunos casos prácticos. Quaderns De Prehistòria i Arqueologia De Catelló, 19, 7-26.

Domínguez-Rodrigo, M., \& Barba, R. (2006). New estimates of tooth mark and percussion mark frequencies at the FLK Zinj site: The carnivore-hominid-carnivore hypothesis falsified. Journal of Human Evolution, 50, 170-194. https://doi.org/10.1016/j.jhevol.2005.09.005

Domínguez-Rodrigo, M. Barba, R. \& Egeland, C. P. (Eds.), Deconstructing Olduvai: A Taphonomic Study of the Bed I Sites. Springer. 337p.

Domínguez-Rodrigo, M., \& Barba, R. (2007a). The behavioral meaning of cut marks at the FLK Zinj level: The carnivore-hominid-carnivore hypothesis falsified (II). In M. Domínguez-Rodrigo, R. Barba, \& C. P. Egeland (Eds.), Deconstructing Olduvai: A Taphonomic Study of the Bed I Sites (pp. 75-100). Springer.

Domínguez-Rodrigo, M., \& Cobo-Sánchez, L. (2017). The spatial patterning of the social organization of modern foraging Homo sapiens: A methodological approach for understanding social organization in prehistoric foragers. Palaeogeography Palaeoclimatology Palaeoecology., 488, 113-125. https:// doi.org/10.1016/j.palaeo.2017.06.008

Domínguez-Rodrigo, M., \& Organista, E. (2007). Natural background bone assemblages and their ravaging stages in Olduvai Bed I. In M. Domínguez-Rodrigo, R. Barba, \& C. P. Egeland (Eds.), Deconstructing Olduvai: A Taphonomic Study of the Bed I Sites (pp. 201-217). Springer.

Domínguez-Rodrigo, M., de la Torre, I., de Luque, L., Alcalá, L., Mora, R., Serralonga, J., \& Medina, V. (2002). The ST Site Complex at Peninj, West Lake Natron, Tanzania: Implications for early hominid behavioural models. Journal of Archaeological Science, 29, 639-665. https://doi.org/10.1006/ jasc.2001.0768

Domínguez-Rodrigo, M., de Juana, S., Galán, A. B., \& Rodríguez, M. (2009a). A new protocol to differentiate trampling marks from butchery cut marks. Journal of Archaeological Science, 36, 26432654. https://doi.org/10.1016/j.jas.2009.07.017

Domínguez-Rodrigo, M., Mabulla, A., Bunn, H. T., Díez-Martín, F., Barba, R., Egeland, C., Yravedra, J., \& Sánchez, P. (2009b). Unravelling hominid behavior at another anthropogenic site from Olduvai Gorge (Tanzania): New archaeological and taphonomic research at BK, Upper Bed II. Journal of Human Evolution, 57, 260-283. https://doi.org/10.1016/j.jhevol.2009.04.006

Domínguez-Rodrigo, M., Mabulla, A. Z. P., Bunn, H. T., Díez-Martín, F., Baquedano, E., Barboni, D., Barba, R., Domínguez-Solera, S., Sánchez, P., Ashley, G. M., \& Yravedra, J. (2010a). Disentangling hominin and carnivore activities near a spring at FLK North (Olduvai Gorge, Tanzania). Quaternary Research, 74, 363-375. https://doi.org/10.1016/j.yqres.2010.07.004

Domínguez-Rodrigo, M., Pickering, T. R., \& Bunn, H. T. (2010b). Configurational approach to identifying the earliest hominin butchers. PNAS, 107, 20929-20934. https://doi.org/10.1073/pnas.10137 11107 
Domínguez-Rodrigo, M., Barba, R., Soto, E., Sesé, C., Santonja, M., Pérez-González, A., Yravedra, J., \& Galán, A. B. (2015). Another window to the subsistence of Middle Pleistocene hominins in Europe: A taphonomic study of Cuesta de la Bajada (Teruel, Spain). Quaternary Science Reviews, 126, 67-95. https://doi.org/10.1016/j.quascirev.2015.08.020

Domínguez-Rodrigo, M., Saladié, P., Cáceres, I., Huguet, R., Yravedra, J., Rodríguez-Hidalgo, P., Martín, P., Pineda, A., Marín, J., Gené, C., Aramendi, J., \& Cobo-Sánchez, L. (2017). Use and abuse of cut marks analyses: The Rorschach effect. Journal of Archaeological Science, 86, 14-23. https:// doi.org/10.1016/j.jas.2017.08.001

Domínguez-Rodrigo, M., Cobo-Sánchez, L., Yravedra, J., Uribelarrea, D., Arriaza, C., Organista, E., \& Baquedano, E. (2018). Fluvial spatial taphonomy: A new method for the study of post-depositional processes. Archaeological and Anthropological Sciences, 10, 1769-1789. https://doi.org/10.1007/ s12520-017-0497-2

Domínguez-Rodrigo, M., Baquedano, E., Barba, R., Uribelarrea, D., \& Gidna, A. (2019a). The river that never was: Fluvial taphonomy at Olduvai Bed I and II sites and its bearing on early human behavior. Quaternary International, 526, 26-380. https://doi.org/10.1016/j.quaint.2019.09.038

Domínguez-Rodrigo, M., Saladié, P., Cáceres, I., Huguet, R., Yravedra, J., Rodríguez-Hidalgo, P., Martín, P., Pineda, A., Marín, J., Gené, C., Aramendi, J., Cobo-Sánchez, L.Spilled ink blots the mind: A reply to Merrit, et al. (2019b). (2018) on subjectivity and bone surface modifications. Journal of Archaeological Science, 102, 80-86. https://doi.org/10.1016/j.jas.2018.09.003

Domínguez-Rodrigo, M. Barba, R. (2007b) A palimpsest at FLK North 1-2: Independent carnivore- and hominid-made bone accumulations. In: Domínguez-Rodrigo, M. Barba, R. Egeland, C.P. (Eds.), Deconstructing Olduvai. A Taphonomic Study of the Bed I Sites. Springer, 127-164.

Domínguez-Rodrigo, M. Barba, R. (2007c). Reanalysis of FLK North North 3: Yet another case of a palimpsest? . In: Domínguez-Rodrigo, M. Barba, R. Egeland, C.P. (Eds.), Deconstructing Olduvai. A Taphonomic Study of the Bed I Sites. Springer, 239-252.

Domínguez-Rodrigo, M. (2005). "Artefactos" óseos en Torralba y Ambrona: Estudio de piezas sobre hueso post-craneal depositadas en el Museo Arqueológico Nacional. In: Santoja, M. PérezGonzález, A. (Eds.), Los Yacimientos Paleolíticos de Ambrona y Torralba (Soria). Zona Arqueológica, Museo Arqueológico Regional de Madrid. 282-287.

Egeland, C. P. (2008). Patterns of early hominid site use at Olduvai Gorge. Mitteilungen Der Gesellschaft Für Urgeschichte, 17, 9-37.

Egeland, C. P. (2014). Taphonomic estimates of competition and the role of carnivore avoidance in hominin site use within the Early Pleistocene Olduvai Basin. Quaternary International, 322-323, 95-106. https://doi.org/10.1016/j.quaint.2013.11.021

Egeland, C. P., \& Domínguez-Rodrigo, M. (2008). Taphonomic perspectives on hominid site use and foraging strategies during Bed II times at Olduvai Gorge, Tanzania. Journal of Human Evolution, 55, 1031-1052. https://doi.org/10.1016/j.jhevol.2008.05.021

Egeland, C. P., Pickering, R., Domínguez-Rodrigo, M., \& Brain, C. K. (2004). Disentangling Early Stone Age palimpsests: Determining the functional independence of hominid- and carnivore-derived portions of archaeofauna. Journal of Human Evolution, 47, 343-357. https://doi.org/10.1016/j.jhevol. 2004.08.004

Egeland, C.P. (2007). Zooarchaeological an Taphonomic perspectives on Hominid and carnivore interactions at Olduvai Gorge, Tanzania. Dep. Anthropol. Indiana University.

Espigares, M. P., Martínez-Navarro, B., Palmqvist, P., Ros-Montoya, S., Toro, I., Agustí, J., \& Sala, R. (2013). Homo vs Pachycrocuta: Earliest evidence of competition for an elephant carcass between scavengers at Fuente Nueva-3 (Orce, Spain). Quaternary International, 295, 113-125. https://doi. org/10.1016/j.quaint.2012.09.032

Faith, J. T. y Behrensmeyer, A. K. (2006). Changing patterns of carnivore modification in a landscape bone assemblage, Amboseli Park, Kenya. Journal of Archaeological Science 33,1718-1733.

Faith, J. T., Marean, C. W. y Behrensmeyer, A. K. (2007). Carnivore competition, bone destruction, and bone density. Journal of Archaeological Science 34, 2025-2034.

Fernández-Jalvo, Y., \& Andrews, P. (2003). Experimental effects of water abrasion on bone fragments. Journal of Taphonomy, 1, 147-163.

Fernández-Jalvo, Y., \& Marín-Monfort, M. D. (2008). Experimental taphonomy in museums preparation protocols for skeletons and fossil vertebrates under the scanning electron microscopy. Geobios, 41, $157-181$.

Fernández-Jalvo, Y. (1992). Tafonomía de microvertebrados del complejo cársitco de Atapuerca (Burgos). Departamento de Paleontología. Universidad Complutense de Madrid, pp. 559. 
Freeman, L.G. Howell, C.F. (1982). Acheulean hunters on the Spanish Meseta: Torralba and Ambrona reconsidered. In: 8lst Annual Meeting Ofthe American Anthropological Association.

Fuentes, C. (2005). El bóvido (Artirodactyla, Mammalia) de los yacimientos del Pleistoceno Medio de Torralba y Ambrona (Soria, España)=nov. Sp. Bos antiquus. In: Santoja, M. Pérez-González, A. Machado, M.J. (Eds.), Geología y Patrimonio En La Península Ibérica y El Entorno Mediterráneo. ADEMA, 527-546.

Gaudzinski, S., Bittman, F., Boenigk, W., Frechen, M., \& Kolfschoten, T. V. (1996). Palaeoecology and archaeology of the Käarlich-Seeufer open-air site (Middle Pleistocene) in the Central Rhineland, Germany. Quaternary Research, 46, 319-334.

Gaudzinski-Windheuser, S., Kindler, L., Rabinovich, R., \& Goren-Inbar, N. (2010). Testing heterogeneity in faunal assemblages from archaeological sites. Tumbling and trampling experiments at the earlyMiddle Pleistocene site of Gesher Benot Ya'aqov (Israel). Journal of Archaeological Science, 37, 3170-3190. https://doi.org/10.1016/j.jas.2010.07.018

Giusti, D., \& Arzarello, N. (2016). The need for a taphonomic perspective in spatial analysis: Formation processes at the Early Pleistocene site of Pirro Nord (P13), Apricena, Italy. Journal of Archaeological Science: Reports, 8, 235-249. https://doi.org/10.1016/j.jasrep.2016.06.014

González Echegaray, J. Freeman, L.G. (1998). Le Paléolithique inférieur et moyen en Espagne, Collection l'homme des origenes. Sér. Préhistorie d'Europe. Jéröme Millon.

Haynes, G. (1988). Longitudinal studies of African elephant death bone deposits. Journal of Archaeological Science, 14, 659-668.

Haynes, G., \& Klimowicz, J. (2015). Recent elephant-carcass utilization as a basis for interpreting mammoth exploitation. Quaternary International, 359-360, 19-37. https://doi.org/10.1016/j.quaint. 2013.12.040

Haynes, G., \& Krasinski, K. (2021). Butchering marks on bones of Loxodonta africana (African savanna elephant): Implications for interpreting marks on fossil proboscidean bones. Journal of Archaeological Science: Reports, 33, 102491. https://doi.org/10.1016/j.jasrep.2021.102957

Haynes, G., Krasinski, K., \& Wojtal, P. (2020). Elephant bone breakage and surface marks made by trampling elephants: Implications for interpretations of marked and broken Mammuthus spp Bones. Journal of Archaeological Science: Reports, 37, 102957. https://doi.org/10.1016/j.jasrep.2020. 102491

Haynes, G. (1991). Mammoths, mastodonts and elephants. Biology, behavior and the fossil record. University Press.

Haynes, G. (2005). Las acumulaciones modernas de huesos de elefante como modelo para interpretar Ambrona y otras áreas con fauna fósil a orillas del agua. In: Santoja, M. Pérez González, A. (Eds.), Esperando El Diluvio. Cantabria Hace 200.000 Años. Zona Arqueológica.

Howell, F. C. (1966). Observations on the earlier phases of the European Lower Paleolithic. American Anthropology, 68, 80-201.

Howell, C. F., Butzer, K. W., \& Aguirre, E. (1963). Noticia preliminar sobre el emplazamiento acheulense de Torralba (Soria). Excavaciones Arqueológicas En España, 10, 38.

Howell, C. F. Butzer, K. W. Aguirre, E. (1962). Noticia preliminar sobre el emplazamiento achelense de Torralba. Excavaciones Arqueológicas en España 10.

Howell, F.C. Butzer,K.W., Freeman, L.G. Klein, R. G. (1995). Observations on the Acheulean occupation site of Ambrona (Soria Province, Spain), with particular reference to the investigation (1980 1983) and the lower occupation. Jahrbuch des Römisch-Germanischen Zentralmuseums Mainz 38:33-82

Huguet, R., Cáceres, I., Díez, J.C. Rosell, J. (1999). Estudio tafonómico y zooarqueológico de los restos óseos de macromamíferos de la unidad GII de Galería (Sierra de Atapuerca). In: Carbonell, E. Rosas, A., Díez, C. (Eds.). Atapuerca: Ocupaciones Humanas y Paleoecología del Yacimiento de Galería. Zamora: Junta de Castilla y León. Consejería de Educación: 245-264.

Isaac, G. L. (1971). The diet of early man: Aspects of archaeological evidence from Lower and Middle Pleistocene sites in Africa. World Archaeology, 2(3), 278-299.

Isaac, G. L., \& Crader, D. C. (1981). To what extent where early hominids carnivorous? An archaeological perspective. In R. S. O. Harding \& G. Teleki (Eds.), Omnivorous Primates (pp. 37-103). Columbia University Press.

Isaac, G.L. (1978). The food-sharing behavior of protohuman hominids. In: Isaac, G., Leakey, R. (Eds.), Human Ancestors. W. H. Freeman and Company.

Junod, C. A., \& Pokines, J. T. (2014). Subaerial weathering. In J. Pokines \& S. A. Symes (Eds.), Manual of Forensic Taphonomy (pp. 287-314). CRC Press. 
Klein, R. G. (1978). Stone age predation of large African bovids. Journal of Archaeological Science, 5 , 195-217.

Klein, R. G. (1982). Age (mortality) profiles as a means of distinguishing hunted specimens from scavenged ones in Stone Age archaeological sites. Paleobiology, 8, 151-158.

Klein, R.G. (1987). Reconstructing how early people exploited animals: problems and prospects. In: Nitecki, M.H. Nitecki, D. V (Eds.), The Evolution of Human Hunting. Plenum Press, 11-45.

Kroll, E. M., \& Price, T. D. (1991). The interpretation of archaeological spatial patterning. Plenum Press.

Kübler, S., Owenga, P., Reynolds, S. C., Rucina, S. M., \& King, G. C. P. (2015). Animal movements in the Kenya Rift and evidence for the earliest ambush hunting by hominins. Scientific Reports, 5 , 14011. https://doi.org/10.1038/srep14011

Lam, Y. M. (1992). Variability in the behaviour of spotted hyaenas as taphonomic agents. Journal of Archaeological Science, 19, 389-406.

Leakey, M. (1971). Olduvai Gorge: excavations in beds I and II. 1960-1963. Cambridge University Press.

Lozano-Fernández, I., Bañuls-Cardona, S., Blain, H. A., López-García, J. M., Vallverdú, J., Agustí, J., \& Cuenca-Bescós, G. (2014). Biochronological data inferred from the Early Pleistocene small mammals of the Barranc de la Boella site (Tarragona, north-eastern Spain). Journal of Quaternary Science, 29, 722-728. https://doi.org/10.1002/jqs.2744

Lyman, R. L. (1994). Vertebrate taphonomy. Cambridge University Press.

Lyman, R. L., \& Fox, G. (1989). A critical evaluation of bone weathering as an indication of bone assemblage formation. Journal of Archaeological Science, 16, 293-317.

Madurell-Malapeira, J. Sorbelli, L. Ros-Montoya, S. Martínez-Navarro, B. Vallverdú, J. Pineda, A. Rosas, A. Huguet, R. Cáceres, I. García-Tabernero, A. López-polín, L. Ollé, A. Saladié, P. (2019). Acheulian tools and Villafranchian taxa: The Latest Early Pleistocene large mammal assemblage From Barranc de la Boella (NE Iberian Peninsula). In Martínez-Navarro, B. Palmqvist, P. Espigares, M. P. Ros-Montoya, S. (Ed.): Libro de Resúmenes Xxxv Jornadas de la Sociedad Española de Paleontología: 161-166.

Malerba, G. Thun-Hohenstein, U. Díez, C. Rosell, J. Giacobini, G. Peretto, C. (2000). Cutmarks e pseudocutmarks. Il problema del riconoscimento di tracce di origine antropica e non sui reperti faunistici del sito di Isernia La Pineta. In: Abaco (Ed.), Atti Del II Convegno Nazionale Di Archeozoologia (Asti, 1997). Forlì: 91-97.

Mania, D. Mania, U. (2005). The natural and sociocultural enviroment of Homo erectus at Bilzingsleben, Germany. in: Gamble, C. (Ed.), The Individual Hominid in Context. Archeological Investigations of Lower and Middle Paleolithic Landscapes, Locales and Artefacts. Routledge, 98-114.

Marín-Arroyo, A. B., Landete-Ruiz, M. D., Vidal-Bernabeu, G., Seva-Román, R., González-Morales, M. R., \& Staus, L. G. (2008). Archaeological implications of human-derived manganese coatings: A study of blackened bones in El Mirón Cave, Cantabrian Spain. Journal of Archaeological Science, 35, 801-813. https://doi.org/10.1016/j.jas.2007.06.007

Marrocchino, E. Vaccaro, C. (2006). Nuove osservazioni sulla caratterizzazione petrografica della serie stratigrafica di Isernia La Pineta. In: Peretto, C. and Minelli, A. (Eds.), Preistoria in Molise. Gli insediamenti del territorio di Isernia. Centro Europeo di Ricerche Preistoriche, Collana Ricerche, vol. 3, Aracne Editrice: 26-31.

Moigne, A. M. (1983). Taphonomie des faunes quaternaires de la Caune de l'Arago. Université Pierre et Marie Curie, Paris.

Moigne, A. M., \& Barsky, D. (1999). Large mammals assemblages from Lower Paleolithic sited in France: La Caune de l'Arago, Terra-Amata, Orgnac 3 and Cagny l'Epinette. In S. Gaudsinski \& E. Turner (Eds.), The role of early humans in the accumulations of European Lower and Middle Paleolithic bone assemblages (pp. 219-235). Habelt Verlag.

Moncel, M. H., Moigne, A. M., \& Combier, J. (2005). Pre-Neandertal behaviour during isotopic stage and the beginning of stage 8 . New data concerning fauna and lithics in the different occupation levels of Orgnac 3 (Ardèche, South-East France): Occupation types. Journal of Archaeological Science, 32, 1283-1301. https://doi.org/10.1016/j.jas.2005.03.014

Moncel, M. H., Chacón, M. G., Bouteaux, A., Julien, M. A., \& Patou-Mathis, M. (2007). Ocupación en abrigo durante el estadio isotópico 5: El nivel D del yacimiento de Payre (Ardèche, Francia): Gestión del territorio y actividades dentro del yacimiento. Trabajos De Prehistoria, 64, 55-76. https://doi.org/10.3989/tp.2007.v64.i1.94 
Moncel, M. H., Moigne, A. M., \& Combier, J. (2012). Towards the Middle Paleolithic in Western Europe: The case of Orgnac 3 (southeastern France). Journal of Human Evolution, 63, 653-666. https://doi.org/10.1016/j.jhevol.2012.08.001

Moncel, M., Santagata, C., Pereira, A., Nomade, S., Voinchet, P., Bahain, J.-J., Daujeard, C., Curci, A., Lemorini, C., Hardy, B., Eramo, G., Berto, C., Raynal, J.-P., Arzarello, M., Mecozzi, B., Ianucci, A., Sardella, R., Allegretta, I., Delluniversità, E., ... Piperno, M. (2020). The origin of early Acheulean expansion in Europe $700 \mathrm{ka}$ ago: New findings at Notarchirico (Italy). Scientific Reports, 10, 13802. https://doi.org/10.1038/s41598-020-68617-8

Mosquera, M., Saladié, P., Ollé, A., Cáceres, I., Huguet, R., Villalaín, J. J., Carrancho, Á., Bourlès, D., Braucher, R., \& Vallverdú, J. (2015). Barranc de la Boella (Catalonia, Spain): An Acheulean elephant butchering site from the European late Early Pleistocene. Journal of Quaternary Science, 30, 651-666. https://doi.org/10.1002/jqs.2800

Mosquera, M., Ollé, A., Saladié, P., Cáceres, I., Huguet, R., Rosas, A., Villalaín, J., Carrancho, A., Bourlès, D., Braucher, R., Pineda, A., \& Vallverdú, J. (2016). The Early Acheulean technology of Barranc de la Boella (Catalonia, Spain). Quaternary International, 393, 95-111. https://doi.org/10. 1016/j.quaint.2015.05.005

Müller, W., \& Pasda, C. (2011). Site formation and faunal remains of the Middle Pleistocene site Bilzingsleben. Quartär, 58, 25-49.

Muttoni, G., Scardia, G. K., Swisher, D. V., Manzi, C. S., \& G. (2009). Pleistocene magnetochronology of early hominin sites at Ceprano and Fontana Ranuccio, Italy. Earth Planet Scientific Letters, 286, 255-268. https://doi.org/10.1016/j.eps1.2009.06.032

Ollé, A. (2005). Variabilitat i patrons funcionals en els sistemes tècnics de mode 2. Anàlisi de les deformacions d'ús en els conjunts lítics del Riparo Esterno de Grotta Paglicci (Rigano Garganico, Foggia), Aridos (Arganda, Madrid) i Galeria-TN (Atapuerca, Burgos). Dep. 'Història i Història de l'Art, Universitat Rovira i Virgili, Tarragona.Ph.D.

Olsen, S., \& Shipman, P. (1988). Surface modification on bone: Tramling versus butchery. Journal of Archaeological Science, 15, 535-553.

Pante, M. C., \& Blumenschine, R. J. (2010). Fluvial transport of bovid long bones fragmented by the feeding activities of hominins and carnivores. Journal of Archaeological Science, 37(4), 846-854. https://doi.org/10.1016/j.jas.2009.11.014

Peretto, C., Arzarello, M., Gallotti, R., Lembo, G. T., \& Hohenstein, U. (2004). Middle Pleistocene behavioural strategies: The contribution of Isernia La Pineta site (Molise, Italy). In E. Baquedano \& S. Rubio Jara (Eds.), Miscelánea en homenaje a Emiliano Aguirre (pp. 368-381). Museo Arqueológico Regional.

Peretto, C., Arnaud, J., Moggi-Cecchi, J., Manzi, G., Nomade, S., Pereira, A., Falguères, C., Bahain, J. L., Grimaud-Hervé, D., Berto, C., Sala, B., Lembo, G., Muttillo, B., Gallotti, R. T., Hohenstein, U., Vaccaro, C., Coltorti, M., \& Arzarello, M. (2015). A human deciduous tooth and new 40Ar/39Ar dating results from the middle pleistocene archaeological site of Isernia La Pineta Southern Italy. PLOS One, 10, e0140091. https://doi.org/10.1371/journal.pone.0140091

Petraglia, M. D., \& Potts, R. (1994). Water flow and the formation of Early Pleistocene artifact sites in Olduvai Gorge, Tanzania. Journal of Anthropological Archaeology, 13, 228-254.

Pickering, T. R., \& Egeland, C. P. (2006). Experimental patterns of hammerstone percussion damage on bones: Implications for inferences of carcass processing by humans. Journal of Archaeological Science, 33, 459-469. https://doi.org/10.1016/j.jas.2005.09.001

Pineda, A., \& Saladié, P. (2019). The Middle Pleistocene site of Torralba (Soria, Spain): A taphonomic view of the Marquis de Cerralbo and Howell faunal collections. Archaeological and Anthropological Sciences., 11, 2539-2556. https://doi.org/10.1007/s12520-018-0686-7

Pineda, A., Saladié, P., Vergès, J. M., Huguet, R., Cáceres, I., \& Vallverdú, J. (2014). Trampling versus cut marks on chemically altered surfaces: An experimental approach and archaeological application at the Barranc de la Boella site (la Canonja, Tarragona, Spain). Journal of Archaeological Science, 50, 84-93. https://doi.org/10.1016/j.jas.2014.06.018

Pineda, A., Saladié, P., Huguet, R., Cáceres, I., Rosas, A., García-Tabernero, A., Estalrrich, A., Mosquera, M., Ollé, A., \& Vallverdú, J. (2015). Coexistence among large predators during the Lower Paleolithic at the site of La Mina (Barranc de la Boella, Tarragona, Spain). Quaternary International, 388, 177-187. https://doi.org/10.1016/j.quaint.2015.05.006

Pineda, A., Saladié, P., Expósito, I., Rodríguez-Hidalgo, A., Cáceres, I., Huguet, R., Rosas, A., LópezPolín, L., Estalrrich, A., García-Tabernero, A., \& Vallverdú, J. (2017a). Characterizing hyena coprolites from two latrines of the Iberian Peninsula during the Early Pleistocene: Gran Dolina (Sierra 
de Atapuerca, Burgos) and la Mina (Barranc de la Boella, Tarragona). Palaeogeography Palaeoclimatology Palaeoecology., 480, 1-17. https://doi.org/10.1016/j.palaeo.2017.04.021

Pineda, A., Saladié, P., Huguet, R., Cáceres, I., Rosas, A., Estalrrich, A., García-Tabernero, A., \& Vallverdú, J. (2017b). Changing competition dynamics among predators at the late Early Pleistocene site Barranc de la Boella (Tarragona, Spain). Palaeogeography Palaeoclimatology Palaeoecology., 477, 10-26. https://doi.org/10.1016/j.palaeo.2017.03.030

Pineda, A., Cáceres, I., Saladié, P., Huguet, R., Morales, J. I., Rosas, A., \& Vallverdú, J. (2019). Tumbling effects on bone surface modifications (BSM): An experimental application on archaeological deposits from the Barranc de la Boella site (Tarragona, Spain). Journal of Archaeological Science, 102, 35-47. https://doi.org/10.1016/j.jas.2018.12.011

Pineda, A., Shannarayapatna, S., Lembo, G., Peretto, C., Saladié, P., \& Thun-Hohenstein, U. (2020). A taphonomic and zooarchaeological study of the early Middle Pleistocene 3 colluvio level from Isernia La Pineta (Molise, Italy). Journal of Archaeological Science: Reports, 33, 102469. https:// doi.org/10.1016/j.jasrep.2020.102469

Piperno, M. Tagliocozzo, A. (2001). The elephant butchery area at the Middle Pleistocene site of Notarchirico (Venosa, Basilicata, Italy). In: Cavarretta, G. Gioia, P. Mussi, M. Palombo, M. R.. (Eds.). The world of elephants - proceedings of the 1st International Congress, Consiglio Nazionale delle Ricerche: 230-236.

Pokines, J. T., King, R. E., Graham, D. D., Costello, A. K., Adams, D. M., Pendray, J. M., Rao, K., \& Siwek, D. (2016). The effects of experimental freeze-thaw cycles to bone as a component of subaerial weathering. Journal of Archaeological Science: Reports, 6, 594-602. https://doi.org/10.1016/j. jasrep.2016.03.023

Pokines, J. T., Faillace, K., Berger, J., Pirtle, D., Sharpe, M., Curtis, A., Lombardi, K., \& Admans, J. (2018). The effects of repeated wet-dry cycles as a component of bone weathering. Journal of Archaeological Science: Reports, 17, 433-441. https://doi.org/10.1016/j.jasrep.2017.11.025

Postigo-Mijarra, J. M., Gómez-Manzanaque, F., \& Morla, C. (2017). Woody macroremains from the Acheulian site of Torralba: Occurrence and palaeoecology of Pinus cf. sylvestris in the Middle Pleistocene of the Iberian Peninsula. Comptes Rendus Palevol, 16, 225-234. https://doi.org/10. 1016/j.crpv.2016.07.004

Potter, R. M., \& Rossman, G. R. (1979). Mineralogy of manganese dendrites and coatings. American Mineralogist, 64, 1219-1226.

Potts, R. (1984). Home base and early hominids. American Sciencentist, 72, 338-349.

Rabinovich, R. Gaudzinski-Windheuser, S. Kindler, L. Goren-Inbar, N. (2012). The Acheulian Site of Gesher Benot Ya'aqov -Volume III - Mammalian Taphonomy. The Assemblages of Layers V-5 and $V$-6. Springer.

Rodríguez-Hidalgo, A., Saladié, P., Ollé, A., \& Carbonell, E. (2015). Hominin subsistence and site function of TD10.1 bone bed level at Gran Dolina site (Atapuerca) during the late Acheulean. Journal of Quaternary Science, 30, 679-701. https://doi.org/10.1002/jqs.2815

Rodríguez-Hidalgo, A., Saladié, P., Ollé, A., Arsuaga, J. L. B., de Castro, J. M., \& Carbonell, E. (2017). Human predatory behavior and the social implications of communal hunting based on evidence from the TD10.2 bison bone bed at Gran Dolina (Atapuerca, Spain). Journal of Human Evolution, 105, 89-122. https://doi.org/10.1016/j.jhevol.2017.01.007

Rosas, A. Saladié, P. Huguet, R. Cáceres, I. Pineda, A. Ollé, A. Mosquera, M. García-Tabernero, A. Estalrrich, A. Pérez-Criado, L. Rodríguez-Pérez, F. Lozano-Fernández, I. López-Polín, L. Moreno, E. Vergès, J.M. Expósito, I. Agustí, J. Carbonell, E. Capdevila, R. Vallverdú, J. (2015). Estudio Preliminar de las Tafofacies del Pleistoceno Inferior del Yacimiento de El Forn (Barranc de la Boella, Tarragona, España). In: Galve, J.P. Azaón, J.M. Pérez Peña, J. V, Ruano, P. (Eds.),XIV Reunión Nacional de Cuaternario, Granada 2015. AEQUA: 46-48.

Rubini, M., Cerroni, V., Festa, G., Sardella, R., \& zaio, P. (2014). A revision of hominin fossil teeth from Fontana Ranuccio (Middle Pleistocene, Anagni, Frosinone, Italy). Journal of Human Evolution, 77, 204-216. https://doi.org/10.1016/j.jhevol.2014.09.002

Sala, B. 1996. Gli animali del giacimento di Isernia La Pineta. In: Peretto, C. (Ed.). I reperti paleontologici del giacimento paleolitico di Isernia La Pineta, l'Uomo e l'ambiente. Istituto Regionale per gli Studi Storici del Molise "V. Cuoco". Isernia, Cosmo Iannone Editore: 87-186.

Saladié, P., Huguet, R., Díez, C., Rosell, J., Cáceres, I., Rodríguez, A., Vallverdú, J. B., de Castro, J. M., \& Carbonell, E. (2011). Carcass transport decisions in Homo antecessor subsistence strategies. Journal of Human Evolution, 61, 425-446. https://doi.org/10.1016/j.jhevol.2011.05.012 
Saladié, P., Rodríguez-Hidalgo, A., Huguet, R., Cáceres, I., Díez, C., Vallverdú, J., Canals, A., Soto, M., Santander, B. B., de Castro, J. M., Arsuaga, J. L., \& Carbonell, E. (2014). The role of carnivores and their relationship to hominin settlements in the TD6-2 level from Gran Dolina (Sierra de Atapuerca, Spain). Quaternary Science Reviews, 93, 47-66. https://doi.org/10.1016/j.quascirev.2014. 04.001

Sánchez-Cervera, B. S., Gómez, M. P., \& A. -González, Domínguez-Rodrigo, M. Sánchez-Romero, L. (2015). La industria lítica del yacimiento achelense de Torralba (Soria, España). Colecciones marqués de Cerralbo y Howell. Trabajos De Prehistoria, 72, 41-63. https://doi.org/10.3989/tp.2015. 12143

Santonja, M., \& Villa, P. (1990). The Lower Paleolithic of Spain and Portugal. Journal of World Prehistory, 4, 45-94.

Santonja, M., Pérez-González, A., Panera, J., Rubio-Jara, S., Sesé, C., Soto, E., \& Sánchez-Romero, L. (2014). Ambrona and Torralba archaeological and palaeontological sites, Soria Province. In R. Sala (Ed.), Pleistocene and Holocene Hunter-Gatherers in Iberia and the Gibraltar Strait: The Current Archaeological Record (pp. 517-527). Universidad de Burgos.

Santonja, M. Pérez-González, A. Mora, R. (2005). Investigaciones recientes (1990-1997) en los yacimientos achelenses de Ambrona y Torralba (Soria, España). In: Santoja, M. Pérez-González, A. (Eds.), Los Yacimientos Paleolíticos de Ambrona y Torralba (Soria). Zona Arqueológica, Museo Arqueológico Regional de Madrid. 104-123.

Segre, A., \& Ascenzi, A. (1984). Fontana Ranuccio: Italy's earliest Middle Pleistocene hominid site. Current Anthropology, 25(230), 233.

Segre-Naldini, E., Muttoni, G., \& PArenti, F. Scardia, G. Segre, A.G. (2009). Nouvelles recherches dans le bassin Plio-Pléistocène d'Anagni (Latium méridional, Italie). L'anthropologie, 113, 66-77. https://doi.org/10.1016/j.anthro.2009.01.013

Selvaggio, M. (1994). Evidence from carnivore tooth marks and stone-tool-butchery marks for scavenging by hominids at FLK Zinjanthropus Olduvai Gorge, Tanzania. Rutgers University, New Jersey. $\mathrm{Ph}$. D. dissertation.

Sesé, C. Soto, E. (2005). Mamíferos del yacimiento del Pleistoceno Medio de Ambrona: Análisis faunístico e interpretación paleoambiental. In: Santoja, M. Pérez-González, A. (Eds.), Los Yacimientos Paleolíticos de Ambrona y Torralba (Soria). Zona Arqueológica, Museo Arqueológico Regional de Madrid. Alcalá de Henares: 258-281.

Shipman, P. (1981). Life history of a fossil. Harvard University Press.

Shipman, P., \& Rose, J. (1983a). Evidence of butchery and hominid activities at Torralba and Ambrona; An evaluation using microscopic techniques. Journal of Archaeological Science, 10, 465-474.

Shipman, P., \& Rose, J. (1983b). Early hominid hunting, butchering, and carcass-processing behaviors: Approaches to the fossil record. Journal of Anthropological Archaeology., 2, 57-98.

Stiner, M. C., Barkai, R., \& Gopher, A. (2009). Cooperative hunting and meat sharing 400-200 kya at Qesem Cave, Israel. PNAS, 106, 13207-13212. https://doi.org/10.1073/pnas.0900564106

Tonon, M. (1989). Note sull'avifauna del deposito di Isernia La Pineta. Il Quaternario, 2, 171-173.

Tuross, N., Behrensmeyer, A. K., \& Eanes, E. D. (1989). Strontium increases and crystallinity changes in taphonomic and archaeological bone. Journal of Archaeological Science, 16, 661-672.

Thun Hohenstein, U., Malerba, G., Giacobini, G., Peretto, C. (2004). Bone surface micromorphological study of the faunal remains from the Lower Palaeolithic site of Isernia La Pineta (Molise, Italy). In: Actes du XIVe Congrès de l'Union Internationale des Sciences Préhistoriques et Protohistoriques, Liegi 2-8 settembre 2001. BAR International Series, vol. 1272, pp. 123-129.

Thun Hohenstein, U., Nucci, A., \& Peretto, C. (2005). Lo sfruttamento di Ursus deningeri nel sito paleolitico di Isernia La Pineta. Atti IV Congresso AIAZ, Quaderni Del Museo Archeologico Del Friuli Occidentale, 6, 23-29.

Thun Hohenstein, U., Nucci, A., \& Moigne, A.-M. (2009). Mode de vie à Isernia La Pineta (Molise, Italie). Stratégie d'exploitation du Bison schoetensacki par les groupes humains au Paléolithique inférieur. L'anthropologie, 113, 96-110. https://doi.org/10.1016/j.anthro.2009.01.009

Vallverdú, J. Saladié, P. Rosas, A. Huguet, R. Cáceres, I. Pineda, A. Ollé, A. Mosquera, M. García-Tabernero, A. Estalrich, A. Carrancho, A. Villalaín, J.J. Bourlès, D. Braucher, R. Lebatard, A. Vilalta, J. Lozano, I. López-Polín, L. Moreno, E. Vergès, J.M. Expósito, I. Agustí, J. Carbonell, E. Capdevila, R. (2014a). El Barranc de La Boella (la Canonja, Tarragona, Catalonia, Spain). In: Sala, 
R. (Ed) (Ed.), Pleistocene and Holocene Hunter-Gatherers in Iberia and the Gibraltar Strait: The Current Archaeological Record. Universidad de Burgos, 287-295.

Vallverdú, J., Saladié, P., Rosas, A., Mosquera, M., Huguet, R., Cáceres, I., García-Tabernero, A., Estalrrich, A., Lozano-Fernández, I., Villalta, J., Esteban-Nadal, M., Benàssar, M. L., Pineda-Alcalá, A., Carrancho, Á., Villalaín, J. J., Bourlès, D., Braucher, R., Lebatard, A., Ollé, A., ... Carbonell, E. (2014b). Age and date for early arrival of the Acheulian in Europe (Barranc de la Boella, la Canonja, Spain). PlosOne, 9, e103634. https://doi.org/10.1371/journal.pone.0103634

Vergès, J.M. (2002). Caracterizaciò dels models d'instrumental litic mode 1 de les dades de l'analisi funcional dels conjunt litotecnics d'Ä̈n Hanech El Kherba (Algeria), Monte Poggiolo i Isernia La Pineta (Italia). Universitat Rovira i Virgili di Tarragona: 411-75. Ph.D.

Villa, P. (1990). Torralba and Aridos: Elephant exploitation in Middle Pleistocene Spain. Journal of Human Evolution, 19, 299-309.

Villa, P., Soto, E., Santonja, M. P., González, A., Mora, R., Parcerisas, J., \& Sesé, C. (2005). New data from Ambrona: Closing the hunting versus scavenging debate. Quaternary International, 126-128, 223-250. https://doi.org/10.1016/j.quaint.2004.03.001

Voormolen, B. (2008). Ancient hunters, modern butchers. Schöningen 13II-4, a kill-butchering site dating from the northwest European Lower Paleolithic. Leiden University.

Whitelaw, T. (1991). Some dimensions of variability in the social organization of community space among foragers. Ethnoarchaeological Approaches to Mobile Campsites: 139-188.

Yravedra, J., Domínguez-Rodrigo, M., Santoja, M., Pérez-González, A., Panera, J., Rubio-Jara, S., \& Baquedano, E. (2010). Cut marks on the Middle Pleistocene elephant carcass of Áridos 2 (Madrid, Spain). Journal of Archaeological Science, 37, 2469-2476. https://doi.org/10.1016/j.jas.2010.05. 007

Yravedra, J., Domínguez-Rodrigo, M., Santonja, M., Rubio-Jara, S., Panera, J., Pérez-González, A., Uribelarrea, D., Egeland, C., Mabulla, A. Z. P., \& Baquedano, E. (2016). The larger mammal palimpsest from TK (Thiongo Korongo), Bed II, Olduvai Gorge, Tanzania. Quaternary International, 417, 3-15. https://doi.org/10.1016/j.quaint.2015.04.013

Yravedra, J. (2000). Implicaciones Tafonómicas y Zooarqueológicas del Paleolítico Inferior de la Península Ibérica. Cuadernos de Prehistoria y Arqueología. Univ. Autónoma Madrid 26: 7-24. https:// doi.org/10.15366/cupauam2000.26.001

Publisher's Note Springer Nature remains neutral with regard to jurisdictional claims in published maps and institutional affiliations.

\section{Authors and Affiliations}

\section{Antonio Pineda ${ }^{1,2}$ (D) Palmira Saladié $2,3,4$}

Palmira Saladié

psaladie@iphes.cat

1 Departamento de Prehistoria, Historia Antigua y Arqueología, Universidad Complutense de Madrid (UCM), Profesor Aranguren s/n, 28040 Madrid, Spain

2 Institut Català de Paleoecologia Humana I Evolució Social (IPHES-CERCA), Zona Educacional 4, Campus Sescelades URV (Edifici W3), 43007 Tarragona, Spain

3 Departament d'Història i Història de l'Art, Universitat Rovira I Virgili, Avinguda de Catalunya 35, 43002 Tarragona, Spain

4 Unit Associated To CSIC, Departamento de Paleobiología, Museo Nacional de Ciencias Naturales (MNCN), Consejo Superior de Investigaciones Científicas (CSIC), Calle José Gutiérrez Abascal, 2, 28006 Madrid, Spain 